\title{
Impact of planetary boundary layer turbulence on model climate and tracer transport
}

\author{
E. L. McGrath-Spangler ${ }^{1,2}$, A. Molod ${ }^{2,3}$, L. E. Ott ${ }^{2}$, and S. Pawson ${ }^{2}$ \\ ${ }^{1}$ Universities Space Research Association, Columbia, MD, USA \\ ${ }^{2}$ Global Modeling and Assimilation Office, NASA Goddard Space Flight Center, Greenbelt, MD, USA \\ ${ }^{3}$ Earth System Sciences Interdisciplinary Center, University of Maryland, College Park, MD, USA \\ Correspondence to: E. L. McGrath-Spangler (erica.l.mcgrath-spangler@nasa.gov)
}

Received: 12 September 2014 - Published in Atmos. Chem. Phys. Discuss.: 16 December 2014

Revised: 15 April 2015 - Accepted: 17 June 2015 - Published: 03 July 2015

\begin{abstract}
Planetary boundary layer (PBL) processes are important for weather, climate, and tracer transport and concentration. One measure of the strength of these processes is the PBL depth. However, no single PBL depth definition exists and several studies have found that the estimated depth can vary substantially based on the definition used. In the Goddard Earth Observing System (GEOS-5) atmospheric general circulation model, the PBL depth is particularly important because it is used to calculate the turbulent length scale that is used in the estimation of turbulent mixing. This study analyzes the impact of using three different PBL depth definitions in this calculation. Two definitions are based on the scalar eddy diffusion coefficient and the third is based on the bulk Richardson number. Over land, the bulk Richardson number definition estimates shallower nocturnal PBLs than the other estimates while over water this definition generally produces deeper PBLs. The near-surface wind velocity, temperature, and specific humidity responses to the change in turbulence are spatially and temporally heterogeneous, resulting in changes to tracer transport and concentrations. Near-surface wind speed increases in the bulk Richardson number experiment cause Saharan dust increases on the order of $1 \times 10^{-4} \mathrm{~kg} \mathrm{~m}^{-2}$ downwind over the Atlantic Ocean. Carbon monoxide (CO) surface concentrations are modified over Africa during boreal summer, producing differences on the order of $20 \mathrm{ppb}$, due to the model's treatment of emissions from biomass burning. While differences in carbon dioxide $\left(\mathrm{CO}_{2}\right)$ are small in the time mean, instantaneous differences are on the order of $10 \mathrm{ppm}$ and these are especially prevalent at high latitude during boreal winter. Understanding the sensitivity of trace gas and aerosol concentration estimates
\end{abstract}

to PBL depth is important for studies seeking to calculate surface fluxes based on near-surface concentrations and for studies projecting future concentrations.

\section{Introduction}

Aerosols exert control over the Earth's climate in several different ways. Directly, they affect the radiative budget through absorption and scattering of both shortwave and long-wave radiation (Sokolik and Toon, 1996; Balkanski et al., 2007). Indirectly, they modify cloud reflectivity and lifetime through greater numbers of cloud condensation nuclei, smaller cloud droplets, and suppressed precipitation (Rosenfeld et al., 2001). Iron contained within aerosol dust enhances biological productivity when transported to the open ocean where it can change oceanic uptake of the greenhouse gas carbon dioxide $\left(\mathrm{CO}_{2}\right)$ through changes to marine photosynthesis (Fung et al., 2000; Jickells et al., 2005; Mahowald, 2011). Ventilation of tracers, such as dust, out of the planetary boundary layer (PBL) for transport downwind is dependent upon PBL turbulent mixing (Sinclair et al., 2008).

$\mathrm{CO}_{2}$ has been increasing at a rate of $1-2 \mathrm{ppm}_{\text {year }}{ }^{-1}$ (Conway et al., 1994) over the last half-century. However, neither the processes controlling nor the locations of the sources and sinks of this greenhouse gas are understood (Davis et al., 2003). $\mathrm{CO}_{2}$ inversion studies, which seek to estimate the magnitude and location of $\mathrm{CO}_{2}$ fluxes, are negatively impacted by PBL depth uncertainty (Gurney et al., 2002; Gerbig et al., 2003; Baker et al., 2006) and this introduces uncertainty into estimates of global climate change. 
Trace gases emitted at the surface are diluted through turbulent mixing in the PBL, and low PBL depths limit vertical mixing and favor higher accumulation of local pollutants near the surface (Pérez et al., 2010; McGrath-Spangler and Denning, 2010; Parrish et al., 2011). Vertical mixing within the PBL therefore affects the magnitude and temporal variability of surface concentrations and vertical mixing near the PBL top affects horizontal advection and downstream concentrations. These factors make accurate simulations of PBL mixing and depth critical for chemistry-transport models (Lin and McElroy, 2010).

In addition to these effects on tracer transport, the PBL depth is important for global climate. Most solar radiation is absorbed at the surface and this energy is transmitted through the rest of the atmosphere through boundary layer processes (Stull, 1988), affecting the global energy cycle. Water vapor is transported from the surface through the boundary layer for lower tropospheric moistening and cloud formation (Stull, 1988). Drying of the PBL as the climate warms therefore has implications for the global hydrological cycle (Sherwood et al., 2014). Furthermore, dynamical processes are affected by the PBL depth such as the tendency of a deeper nocturnal boundary layer to result in a weaker low-level jet (Holtslag et al., 2013).

Several studies have found that the estimated PBL depth varies with the definition used. Seibert et al. (2000) described multiple PBL depth estimation methods using profiles from radiosondes, sodar, and wind profilers, among others. They found the results sensitive to the observing system and algorithm used. Seidel et al. (2010) found that the PBL depth estimated using various definitions from a single atmospheric profile could differ by more than $1 \mathrm{~km}$ and that the general differences among the definitions evaluated were on the order of hundreds of meters. Similarly, Vogelezang and Holtslag (1996) found that the formulation of the Richardson number, the inclusion of a surface friction velocity term, and the critical value of the Richardson number produced different estimates of PBL depth. Using the Goddard Earth Observing System (GEOS-5) model, McGrathSpangler and Molod (2014) evaluated seven PBL depth definitions and found that the largest variations in depth occur for the nocturnal boundary layer and that the PBL depth estimated with Richardson-number-based methods are lower than PBL depths estimated using methods based on the eddy diffusion coefficient. They also found that Richardsonnumber-based methods produce a shallower midday PBL under warm, moist conditions, such as in the tropical rainforest.

The GEOS-5 AGCM (atmospheric general circulation model) uses the PBL depth to inform the calculation of the turbulent length scale at the next time step that then impacts the simulated turbulence and vertical mixing. Several previous studies (e.g., Troen and Mahrt, 1986; Ballard et al., 1991; Mahrt and Vickers, 2003) have used the PBL depth in this calculation. This study seeks to understand the effect of changing the PBL depth definition used within the
GEOS-5 AGCM to estimate the turbulent length scale and the impact on the emission, loss, and transport processes of atmospheric trace gases and aerosols. Section 2 describes the modeling system, PBL depth definitions, numerical experiments, and the validation data sets. Section 3 details the impacts of PBL depth definition on the simulated climate. The impact on tracer concentrations and transport are examined in more detail in Sect. 4. The final section contains the conclusions.

\section{Experiment design}

\subsection{GEOS-5 model description}

The GEOS-5 model is a comprehensive model used in different configurations for simulations of atmospheric dynamics and chemistry, atmospheric data assimilation operational analyses and reanalyses, and seasonal forecasting when coupled to an ocean model (Rienecker et al., 2008; Molod et al., 2012). The finite volume dynamical core on a cubed sphere grid is based on Putman and Lin (2007). Grid-scale moist processes are described in Bacmeister et al. (2006) and Molod et al. (2012) and employ a modified version of relaxed Arakawa-Schubert convective parameterization (Moorthi and Suarez, 1992). The radiation schemes are described by Chou and Suarez (1999, shortwave) and Chou et al. (2001, long wave). The land surface model is the Catchment Land Surface Model (Koster et al., 2000), and the surface layer turbulence is from Helfand and Schubert (1995). Seventy-two vertical layers transition from terrain following near the surface to pure pressure levels above $180 \mathrm{hPa}$.

The GEOS-5 turbulence parameterization uses the nonlocal scheme of Lock et al. (2000) in conjunction with the Richardson-number-based scheme of Louis et al. (1982). The Lock scheme represents non-local mixing in unstable layers only and computes the characteristics of rising or descending parcels of air resulting from surface heating and cloud top cooling of boundary layer clouds. The GEOS-5 implementation includes moist heating in the calculation of buoyancy and a shear-dependent entrainment in the unstable surface parcel calculations. This scheme can treat both clear and cloudy layers and the turbulent eddy diffusion coefficients are computed using a prescribed vertical structure based on the height of the surface or radiative parcels.

The Louis scheme computes eddy diffusion coefficients using Richardson-number-based stability functions for both stable and unstable layers and is a first-order local scheme. This scheme requires the specification of a turbulent length scale, which is formulated using a Blackadar (1962) style interpolation between the height above the surface and a vertical scale based on the PBL height from the previous time step. Although many AGCMs specify the length scale a priori to a constant global value (e.g., Sandu et al., 2013), the GEOS-5 formulation estimates this scale using the PBL 
depth diagnosed from the atmospheric profile from the previous model time step, adding "memory" and a dependence on the atmospheric state to the turbulence parameterization. This study modifies the PBL depth definition used within the Louis-scheme turbulent length-scale calculation and examines the model response. Thus, only the local turbulent mixing scheme is altered though this change indirectly affects the general model climate.

\subsection{GEOS-5 trace gas and aerosol emissions}

The GEOS-5 AGCM includes a prognostic aerosol module based on the Goddard Chemistry, Aerosol, Radiation, and Transport (GOCART; Chin et al., 2002; Colarco et al., 2014) model. In this configuration, GEOS-5 simulates emission, transport, and loss of dust, sea salt, black carbon, organic carbon, and aerosols. The aerosol species are independent of one another. Aerosol loss processes depend on meteorological conditions such as wind and precipitation and the vertical distribution. The model also estimates wet and dry deposition and gravitational settling.

Dust and sea salt emissions depend on GEOS-5 wind speeds near the surface and, as a result, are likely to be particularly sensitive to changes in the model's treatment of turbulent mixing. Dust emissions are based on those of Ginoux et al. (2001) as modified by Chin et al. (2003). The emissions depend on wind speed, particle size, and surface wetness and the location of dust emissions are topographic depression areas with bare soil surfaces (Chin et al., 2003). Dust optical properties are prescribed based on data from the Aerosol Robotic Network (AERONET) (Holben et al., 1998) across the visible spectrum merged with the OPAC (Optical Properties of Aerosols and Clouds) data set in the long wave (Randles et al., 2013). Sea salt emissions are computed as a function of sea salt particle radius and frictional velocity based on Gong (2003).

GEOS-5 also simulates emission and transport of a number of trace gases including $\mathrm{CO}$ and $\mathrm{CO}_{2}$, which are evaluated in this study. Prescribed land and ocean $\mathrm{CO}_{2}$ fluxes were computed as part of NASA's Carbon Monitoring System project and are described in detail in Ott et al. (2015). Three hourly net ecosystem production of $\mathrm{CO}_{2}$ is computed by the Carnegie-Ames-Stanford Approach Global Fire Emissions Database, version 3 (CASA-GFED3) biogeochemical model (Potter et al., 1993; Randerson et al., 1996). GFED3 biomass burning emissions are based on satellite estimates of area burned, fire activity, and plant productivity from the MODerate-resolution Imaging Spectroradiometer (MODIS) (van der Werf et al., 2010). Ocean $\mathrm{CO}_{2}$ fluxes are computed as a function of sea surface temperature, surface salinity, and partial pressure of $\mathrm{CO}_{2}$, computed by the NASA Ocean Biogeochemical Model (Gregg, 2000, 2002; Gregg et al., 2003; Gregg and Casey, 2007) and $10 \mathrm{~m}$ wind speed and atmospheric $\mathrm{CO}_{2}$ from the GEOS-5 AGCM. Fossil fuel emissions are from the Carbon Dioxide Information Analysis Center
(CDIAC) computed using the procedure described by Marland and Rotty (1984; Marland et al., 2008).

Carbon monoxide (CO) emissions follow those of Duncan et al. (2007) and Duncan and Logan (2008). The Global Modeling Initiative chemistry and transport model simulations were used to calculate methane and hydroxyl climatologies to estimate chemical production and loss in a computationally efficient manner. Biofuel emissions of $\mathrm{CO}$ are from Yevich and Logan (2003) and biomass burning estimates are from the daily Quick Fire Emission Database (Darmenov and da Silva, 2015).

\subsection{PBL depth definitions}

McGrath-Spangler and Molod (2014) evaluated various PBL depth definitions diagnostically, but the analysis did not include any PBL depth feedback on the turbulent length scale and therefore on the simulated climate. The present analysis examines the impact of three of those PBL depth definitions (summarized in Table 1) on tracer transport through their use in calculating the turbulent length scale. In this way, the different PBL depths are able to affect the climate and tracer transport within the model.

The first definition evaluated here is the method used to estimate the PBL depth in MERRA (Modern-Era Retrospective Analysis for Research and Applications) and MERRA2 (Method 1 from McGrath-Spangler and Molod, 2014). This method evaluates the vertical profile of the eddy diffusion coefficient of heat $\left(K_{\mathrm{h}}\right)$. The PBL height is estimated as the height of the model level below which $K_{\mathrm{h}}$ falls below a threshold value of $2 \mathrm{~m}^{2} \mathrm{~s}^{-1}$.

The second method (Method 2 of McGrath-Spangler and Molod, 2014) is also based on the vertical profile of $K_{\mathrm{h}}$, but uses a variable threshold equal to $10 \%$ of the column maximum $K_{\mathrm{h}}$ and linearly interpolates between model levels. The variable threshold was chosen because of its state dependence and therefore its spatiotemporal variability.

The final method evaluated here is Method 4 of McGrathSpangler and Molod (2014) and depends on a bulk Richardson number as described by Seidel et al. (2012). This definition is suitable for both convective and stable boundary layers and was shown by McGrath-Spangler and Molod (2014) to produce a more realistic diurnal cycle of PBL depth over many land areas. The bulk Richardson number $\left(R i_{\mathrm{b}}\right)$ is given by

$R i_{\mathrm{b}}(z)=\frac{\left(\frac{g}{\theta_{\mathrm{vs}}}\right)\left(\theta_{\mathrm{v} z}-\theta_{\mathrm{vs}}\right)\left(z-z_{\mathrm{s}}\right)}{u_{z}^{2}+v_{z}^{2}}$,

where $g$ is gravitational acceleration, $\theta_{\mathrm{v}}$ is the virtual potential temperature, $u$ and $v$ are the horizontal wind components, and $z$ is height above the ground. The subscript $s$ denotes the surface and the bulk Richardson number is evaluated between the surface and successively higher levels. Surface winds are assumed negligible. The PBL top is found by 
Table 1. Summary of PBL depth methods.

\begin{tabular}{lll}
\hline Method/experiment & Abbreviation & Description \\
\hline 1 & $K_{\mathrm{h}}: 2$ & Uses $K_{\mathrm{h}}$ and a threshold of $2 \mathrm{~m}^{2} \mathrm{~s}^{-1}$ \\
2 & $K_{\mathrm{h}}: 10 \%$ & Uses $K_{\mathrm{h}}$ and a threshold equal to $10 \%$ of the column maximum \\
3 & Bulk $R i$ & Uses the bulk Richardson number described by Seidel et al. (2012) and a critical value of 0.25 \\
\hline
\end{tabular}

linearly interpolating between model levels using a critical value of 0.25 .

\subsection{Experimental configuration}

In order to isolate the climate response to PBL depth from internal model variability, model ensembles are run with 10 simulations for each of the three PBL depth definitions from January 2009 through February 2010. Ensemble means are used for the comparisons here. Each ensemble is initialized using MERRA reanalysis data from a different day (between 15 November and 15 December 2008) although all simulations begin on 30 November 2008. The first month of each simulation is disregarded as a spin-up period and is not used in the analysis. The simulations are on a cubed sphere grid with approximately $2^{\circ}$ horizontal resolution. While sea surface temperature and emission data sets from 2008 are used, all simulations are run in GEOS-5 "climate mode" with no constraint by meteorological reanalyses.

\subsection{Validation data}

The ensemble means of the simulations using the different PBL height definitions are compared here to various observational data sets in a climatological sense to provide validation of meteorological and tracer fields. The MERRA reanalysis used a three-dimensional variational data assimilation (3DVAR) analysis algorithm to incorporate observations from conventional and satellite-based data sources (Rienecker et al., 2011).

Aerosol optical thickness (AOT) data are available from the MODIS (Remer et al., 2005) and the Multi-angle Imaging SpectroRadiometer (MISR, Kahn et al., 2010) instruments for comparison with the free-running model. The MERRA Aerosol (MERRAero, Kishcha et al., 2014) reanalysis uses MERRA estimated meteorology, assimilates MODIS AOT data, and provides data on dust, sea salt, sulfates, and black and organic carbon. MERRAero data provide global aerosol concentrations at 3-hourly intervals.

The Measurement of Pollution in the Troposphere (MOPITT) instrument is a mission designed to measure carbon monoxide (CO) from space in order to quantify tropospheric pollution. It uses a nadir IR correlation radiometer with a field of view of $22 \mathrm{~km} \times 22 \mathrm{~km}$ (Drummond and Mand, 1996). This study uses the TIR/NIR version 5 data.

The Atmospheric $\mathrm{CO}_{2}$ Observations from Space (ACOS version 3.4) project estimates column $\mathrm{CO}_{2}$ using obser- vations from the Greenhouse Gases Observing Satellite (GOSAT). GOSAT's onboard instrument, the Thermal And Near-infrared Sensor for carbon Observation Fourier Transform Spectrometer (TANSO-FTS), measures spectra of reflected sunlight in order to make this estimate (Yokota et al., 2004; Hamazaki et al., 2005). Details of the ACOS retrieval can be found in Wunch et al. (2011), O'Dell et al. (2012), and Crisp et al. (2012).

The International Satellite Cloud Climatology Project (ISCCP) data set contains a global climatology of cloud properties derived from infrared and visible radiances (Rossow and Schiffer, 1991, 1999) with the goal of improving the understanding of the effects of clouds on climate, the radiation budget, and the global hydrological cycle.

\section{Impact on model climate}

Observational and modeling studies have found that different PBL depth estimation methods can produce depth estimates that vary by hundreds of meters, even when analyzing the same atmospheric profile (e.g., Seidel et al., 2010; McGrathSpangler and Molod, 2014). In this study, the methods evaluated depend on different atmospheric variables with the bulk $R i$ method dependent on vertical profiles of temperature and wind speed and the two $K_{\mathrm{h}}$ methods dependent on vertical profiles of turbulent eddy diffusion coefficients. McGrathSpangler and Molod (2014) found that over land these differences result in lower nocturnal PBL depths estimated by the bulk $R i$ method due to persistent turbulence and elevated $K_{\mathrm{h}}$ aloft throughout the diurnal cycle, resulting in deeper PBL estimates using methods 1 and 2 . The methodological differences resulted in differences in the climatological mean estimates. Thus, differences in definition alone can result in a shallower nocturnal PBL estimated using the bulk Richardson number method. This behavior can be expected in these experiments.

Evidence of this can be found in Fig. 1, which shows the June-August (JJA) time mean PBL depth diurnal cycle averaged over northern Africa and tropical South America. Over northern Africa, it can be seen that the PBL depth estimated by the two methods dependent on the turbulent eddy diffusion coefficient are similar with depths within a few hundred meters of each other throughout the diurnal cycle. The bulk Richardson number method, sensitive to temperature and wind profiles, estimates a similar daytime maximum depth, however, the estimated nocturnal depth is lower, by as 

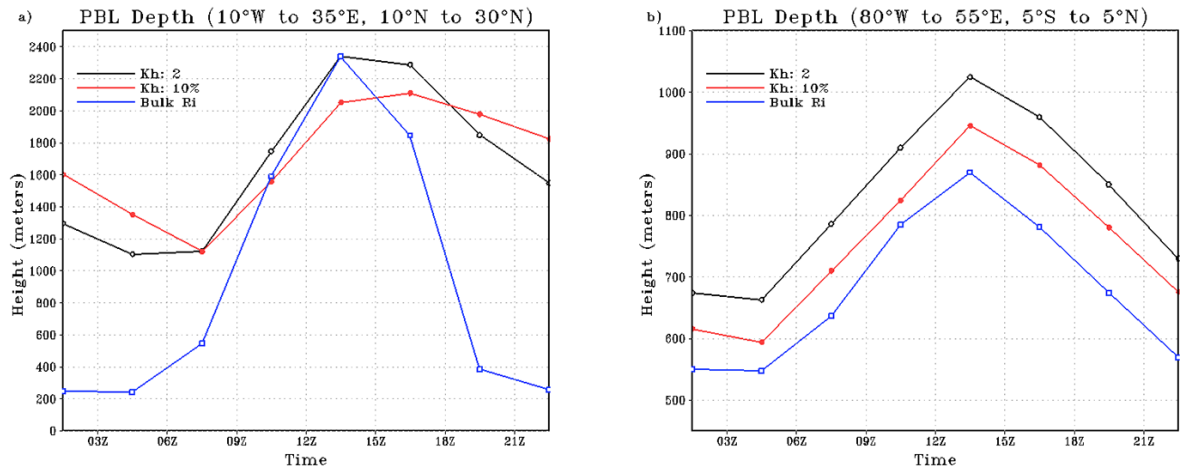

Figure 1. Diurnal cycle of JJA mean PBL depth averaged over northern Africa from $10^{\circ} \mathrm{W}$ to $35^{\circ} \mathrm{E}$ longitude and from 10 to $30^{\circ} \mathrm{N}$ latitude (a) and tropical South America from $80^{\circ} \mathrm{W}$ to $55^{\circ} \mathrm{E}$ longitude and from $5^{\circ} \mathrm{S}$ to $5^{\circ} \mathrm{N}(\mathbf{b})$.

much as $1 \mathrm{~km}$ or more. Consistent with McGrath-Spangler and Molod (2014), this indicates the presence of a stable layer below the height of turbulence decay. Over tropical South America, experiment 3 (bulk Ri) estimates a similar depth to the other two methods though it is consistently a few hundred meters less, again consistent with the results of McGrath-Spangler and Molod (2014).

These differences in PBL depth have consequences for land-atmosphere interactions. Shallower PBLs result in a shallower turbulent layer so that surface fluxes are not mixed as high vertically and boundary layer top entrainment occurs at a lower height. Lower boundary layer top entrainment results in entrained air having a lower potential temperature than if the entrainment occurred higher, which is due to increasing potential temperature with height. Beljaars and Betts (1992) found in their study that the proper representation of entrainment is essential to correctly simulate nearsurface atmospheric conditions with too low PBL depth estimates resulting in a near-surface atmosphere that is too cool and too moist. PBL depth differences thus change the atmospheric conditions to which the surface responds through differences in the temperature and humidity gradients between the atmosphere and the surface (McGrath-Spangler et al., 2009; McGrath-Spangler and Denning, 2010). Changes to the surface sensible and latent heat fluxes can result in modifications to the moisture and energy available at cloud layer and produce either increases or decreases in cloud amount. This, in turn, produces changes in cloud albedo and the vertical redistribution of short- and long-wave radiation.

Seasonal mean PBL depth (Fig. 2) differences among the three ensemble means are generally similar to the differences described in McGrath-Spangler and Molod (2014). Over land, Method $1\left(K_{\mathrm{h}}: 2\right)$ estimates the greatest PBL depths in both seasons while Method 3 (bulk Ri) estimates lower depths due largely to a better representation of the shallow nighttime PBL. Over the Southern Ocean, the bulk $R i$ method (Method 3) generally estimates the deepest PBLs, indicative of a shallow turbulence layer defined by $K_{\mathrm{h}}$ rela-
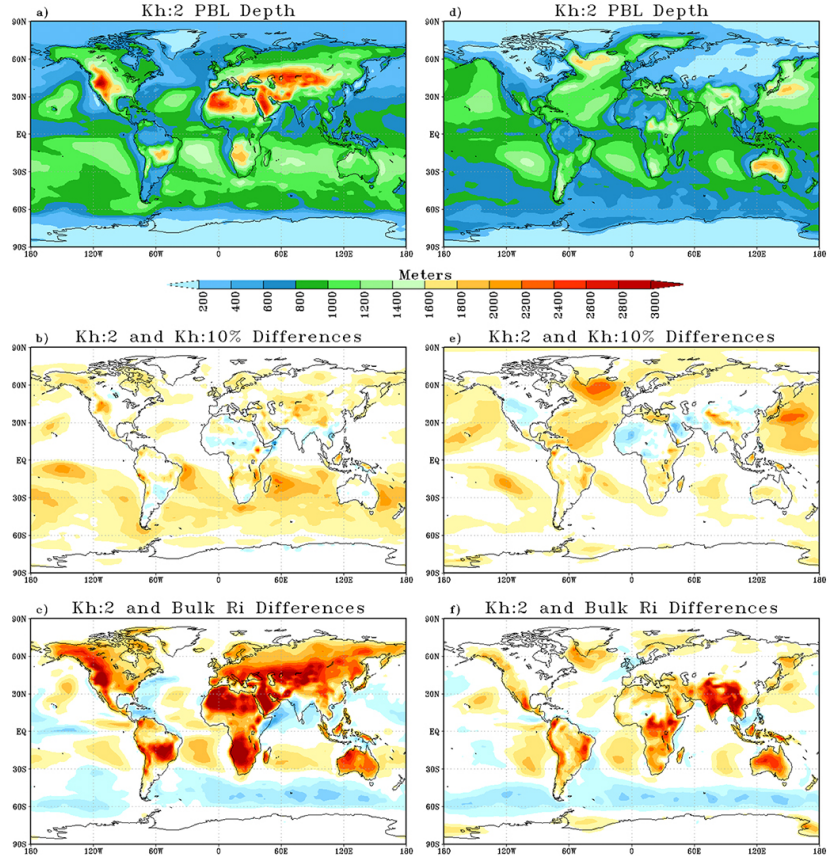

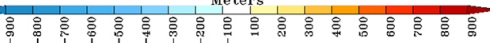

Figure 2. Seasonal mean PBL depth estimated by the $K_{\mathrm{h}}$ : 2 PBL depth estimation method for JJA (a) and DJF (d), the differences between the $K_{\mathrm{h}}: 2$ and $K_{\mathrm{h}}: 10 \%$ methods during JJA (b) and DJF (e), and the differences between the $K_{\mathrm{h}}: 2$ and bulk $R i$ methods during JJA (c) and DJF (f).

tive to the unstable layer as defined by the bulk Richardson number.

Over much of the Northern Hemisphere land, Method 1 $\left(K_{\mathrm{h}}: 2\right)$ estimates a greater PBL depth than Method $2\left(K_{\mathrm{h}}\right.$ : $10 \%)$ during JJA. This implies that in these areas, $10 \%$ of the column maximum $K_{\mathrm{h}}$ is greater than the $2 \mathrm{~m}^{2} \mathrm{~s}^{-1}$ threshold used by Method 1 and there is relatively strong nearsurface turbulence. During DJF, Method 2 estimates deeper PBLs than does Method 1 over much of the winter hemi- 

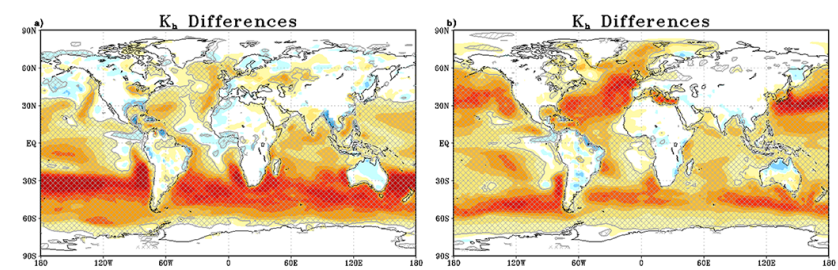

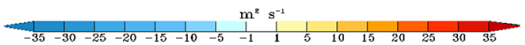

Figure 3. Seasonal mean turbulent eddy diffusion coefficient at $925 \mathrm{hPa}$ differences (Method 3 minus Method 2) for JJA (a) and DJF (b). Hatch marks represent significance at the $90 \%$ level using the Student's $t$ test. Crosshatch marks represent significance at the $95 \%$ level.

sphere land, indicating weaker turbulence, consistent with greater atmospheric stability and suppressed turbulence over land during the colder months. This seasonal pattern is a result of the differences in solar insolation. Over water, in most areas, Method 1 produces deeper PBLs than does Method 2. However, since they both depend on the turbulent eddy diffusion coefficient, in general, methods 1 and 2 are more similar to each other than they are to Method 3. Since differences between these methods are minimal, the remainder of this discussion concentrates on differences between methods 2 and 3.

The turbulent eddy diffusion coefficient is dependent on PBL depth as changes in its estimation produce changes in $K_{\mathrm{h}}$. Under unstable conditions, as the PBL depth increases, the Louis-scheme length scale used in the calculation of the turbulent eddy diffusion coefficient for this scheme also increases. Since the total eddy diffusion coefficient is a combination of those computed by the Louis and Lock schemes, an increase in the PBL depth can lead to an increase in $K_{\mathrm{h}}$ and the turbulent mixing.

The largest $K_{\mathrm{h}}$ (Fig. 3) differences in the lower troposphere occur over the southern hemispheric oceans and along the Atlantic and Pacific oceans' wintertime storm tracks where Method 3 (bulk Ri) estimates deeper PBLs. Midday PBL depths over land (Fig. 1) estimated by the three methods are similar, producing small turbulent length-scale differences and a small impact on turbulence. At night, PBL depth differences are much larger over land, producing correspondingly different turbulent length scales among the simulations. However, nighttime conditions are generally stable and the turbulent length scale is unused in the calculation of turbulence. Differences over land, therefore, primarily result from feedbacks between the large-scale meteorology and the turbulence.

These changes in turbulence lead to changes in the simulated climate of the model. Figure 4 shows the impact on the mean meridional circulation. Significant differences are present between the two simulations in the estimation of the Hadley cell during DJF and JJA. For experiment 3 (bulk Ri), the strength of the inner core of the Hadley cell is increased in the DJF and JJA seasons. A weakening of the northern edge of the Hadley circulation is present in DJF, indicating less subsidence around $30^{\circ} \mathrm{N}$. During the transition seasons of March-May (MAM) and September-November (SON), the differences between the bulk $R i$ and $K_{\mathrm{h}}: 10 \%$ experiments are smaller than during JJA and DJF and the area of significant differences is less. In all four seasons, the latitude of the maximum zonal mean precipitation is unchanged (Fig. 5), indicating that there is not a shift in the position of the Intertropical Convergence Zone (ITCZ); however, the magnitude of precipitation along the ITCZ is greater in experiment 3 (bulk $R i$ ). The increase in precipitation is consistent with the increase in latent heat flux (Fig. 6), and therefore atmospheric water vapor, in experiment 3.

Figure 6 shows the effect of changing the PBL depth definition used to estimate the turbulent length scale on latent and sensible heat fluxes. There is a decrease in the Bowen ratio resulting from a decrease in the sensible heat and an increase in the latent heat fluxes over much of the tropical and subtropical oceans. The Bowen ratio shift is consistent with an increase in the surface-atmosphere humidity gradient and a decrease in the temperature gradient. This could result from boundary layer top entrainment of warmer and drier air. Due to a general decrease of specific humidity and an increase of potential temperature with height this is compatible with a deeper PBL in experiment 3.

Changes in the turbulence and mean circulation result in a redistribution of atmospheric mass that can be seen as changes in the surface pressure and the mid-latitude jets (Fig. 7). Seasonal mean pressure changes mostly occur in regions over the Southern Ocean with a magnitude on the order of 1 to $2 \mathrm{hPa}$. The jets are displaced slightly southward throughout the vertical column in the Southern Hemisphere during JJA and above about $700 \mathrm{hPa}$ in the Northern Hemisphere during DJF, consistent with the changes in surface pressure. These differences produce changes to the pressure gradient force and are associated with differences in the spatial patterns of the near-surface wind.

Figure 8 compares the $10 \mathrm{~m}$ wind speed estimated using the bulk $R i$ method (Method 3) and the $K_{\mathrm{h}}: 10 \%$ method (Method 2) and the MERRA reanalysis estimate. Significant differences between the simulations occur over the Southern Ocean south of the African continent during JJA and southwest of South America in both seasons. During JJA, this increase in wind speed for experiment 3 is a result of a deeper low pressure over Antarctica from $60^{\circ} \mathrm{W}$ to the dateline and increased pressure over the southern Pacific and Indian oceans from approximately 30 to $60^{\circ} \mathrm{S}$. These changes lead to an improved estimate of the wind speed relative to MERRA. During DJF, the change in pressure gradient is reversed, leading to a decrease in the wind speed and degradation of the estimate relative to MERRA.

During JJA, experiment 3 (bulk $R i$ ) has increased easterly winds over the Atlantic Ocean relative to experiment $2\left(K_{\mathrm{h}}\right.$ : 

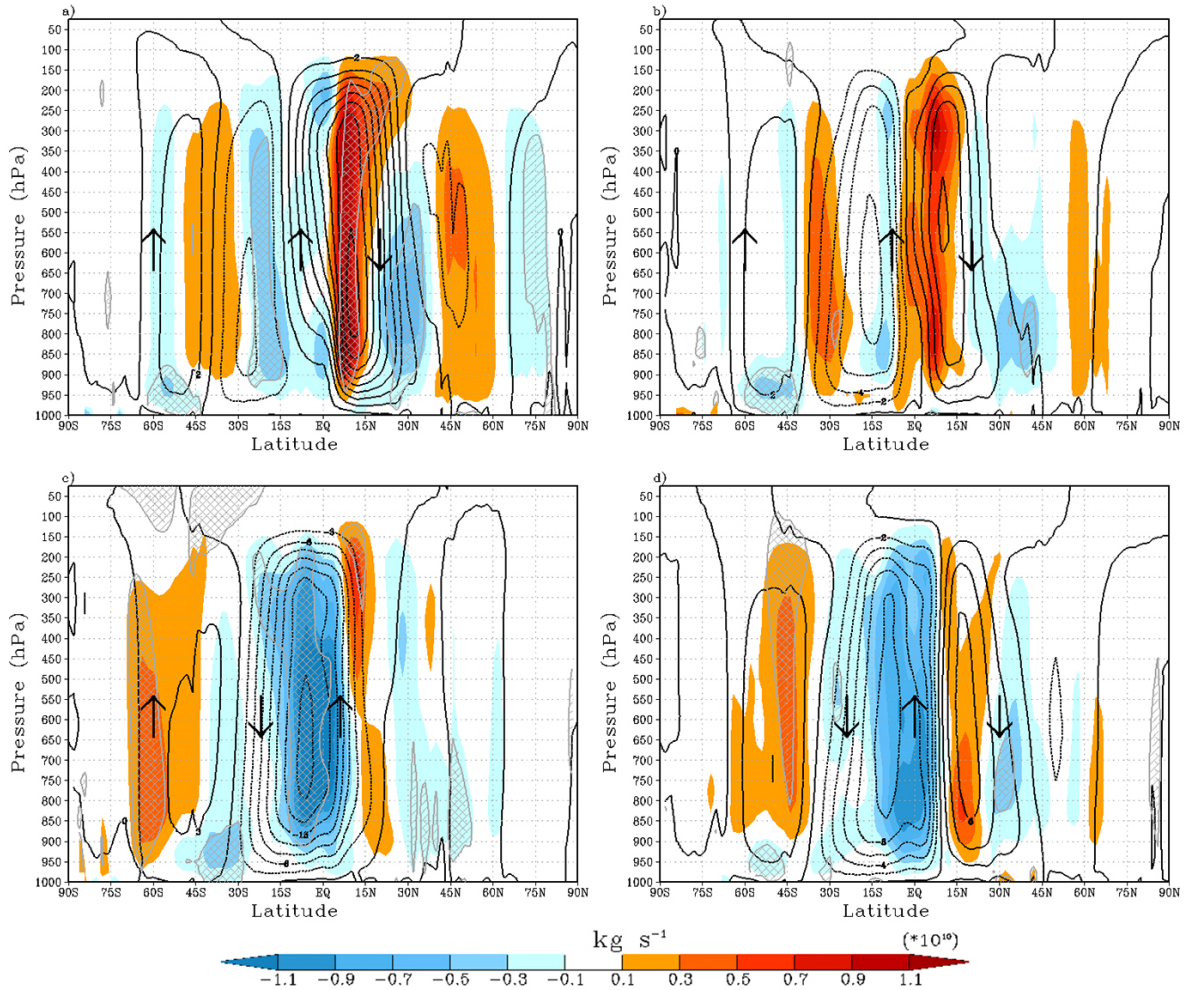

Figure 4. Seasonal mean difference (Method 3 minus Method 2; shaded) and average (contours) mean meridional circulation for (a) DJF, (b) MAM, (c) JJA, and (d) SON. Positive (negative) values are represented by solid (dashed) lines. Arrows indicate the sense of the circulation. Hatch marks represent significance at the $90 \%$ level using the Student's $t$ test. Crosshatch marks represent significance at the $95 \%$ level.

$10 \%)$ associated with a stronger Atlantic subtropical high. Experiment 2's wind speed in this region is greater than in MERRA and the increase in experiment 3 exacerbates the disagreement. There is also an increase in wind speed over the Pacific Ocean associated with decreased pressure over the Asian continent in experiment 3, which is an improvement when compared to MERRA relative to experiment 2.

In addition to the winds, near-surface temperature is sensitive to changes in the PBL depth estimate used to calculate the turbulent length scale. Figure 9 shows the $2 \mathrm{~m}$ temperature differences between experiments 2 and 3 (bulk $R i$ and $\left.K_{\mathrm{h}}: 10 \%\right)$ relative to the temperature estimated by MERRA. Significant temperature differences are present over the tropical land areas of the Amazon, Congo, and the maritime continent with experiment 3 simulating cooler temperatures that are consistent with entrainment of lower potential temperature air during PBL depth growth. These are the regions associated with a lower midday PBL depth diagnosed by the bulk Richardson number method relative to the turbulent eddy diffusion coefficient methods in Fig. 1b and in McGrathSpangler and Molod (2014).

During DJF, the bulk Ri experiment simulates cooler temperatures in the Pacific Northwest of the United States and at high northern latitudes. These changes are associated with less surface absorbed long-wave radiation. Over most land areas, the free-running GEOS-5 AGCM overestimates the temperature relative to MERRA (Molod et al., 2012) so a temperature decrease is generally an improvement.

Changes in near-surface specific humidity (Fig. 10) also result from changes to the PBL depth estimate used in the turbulent length-scale calculations; most regions experience lower humidity levels in experiment 3 (bulk $R i$ ). The Great Lakes region of the United States, during JJA, experiences a larger diurnal cycle of the PBL depth using Method 3 (bulk $R i)$ than when using Method $2\left(K_{\mathrm{h}}: 10 \%\right.$ experiment) due to lower nocturnal PBL depths combined with greater daytime depths. This is associated with warmer temperatures and lower humidity, consistent with entrainment of warmer and drier free tropospheric air into the boundary layer. These specific humidity differences are on the order of $1 \mathrm{~g} \mathrm{~kg}^{-1}$ or about $10 \%$ of the mean value and are more similar to MERRA.

Land areas with significantly higher estimated specific humidity in experiment 3 (bulk $R i$ ) are associated with decreased near-surface temperatures. This suggests less incorporation of warm, dry free tropospheric air into the boundary layer. Significant differences in these regions are on the order of $10-20 \%$ of the mean total. Significant specific humid- 

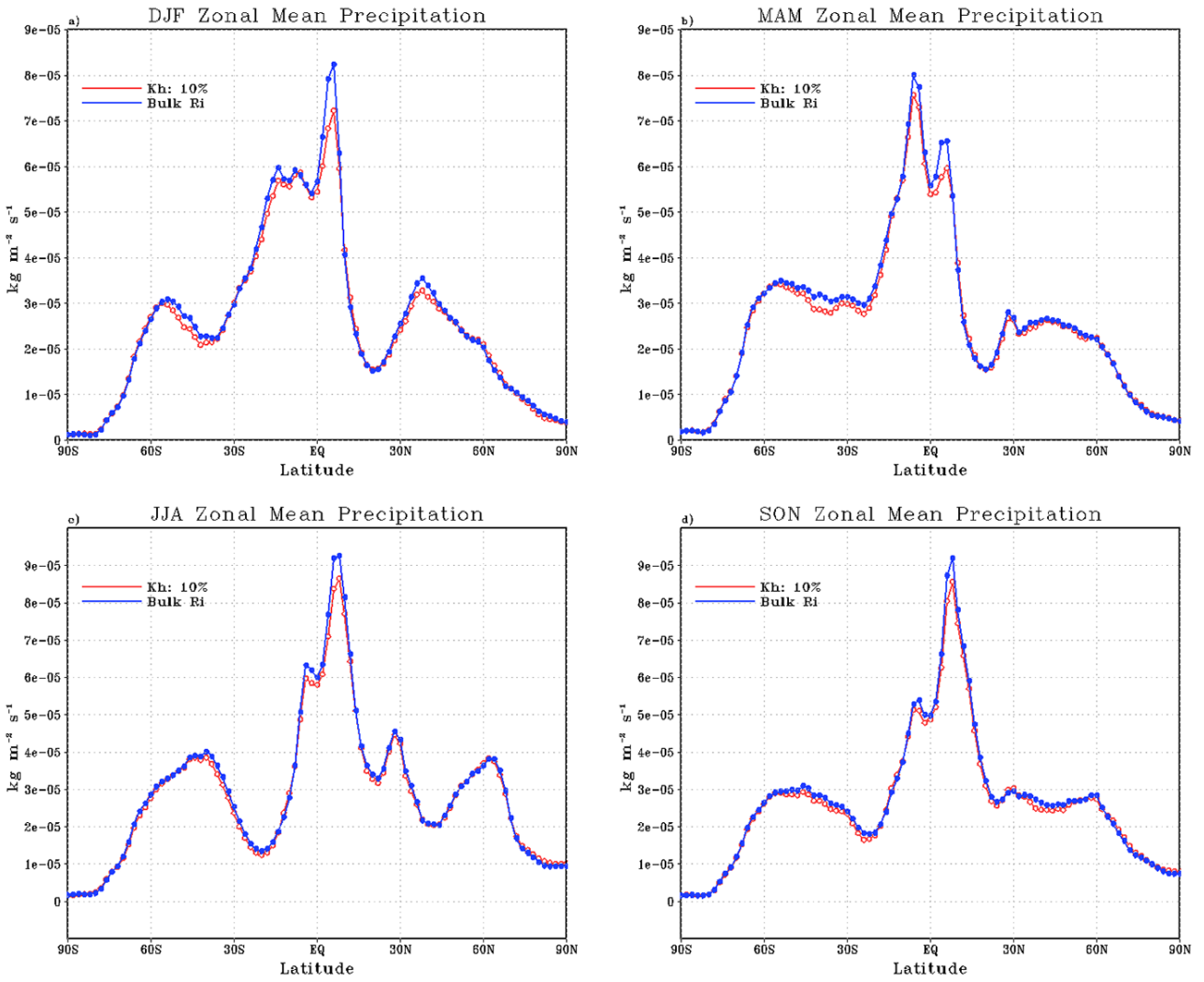

Figure 5. Seasonal mean zonal precipitation for (a) DJF, (b) MAM, (c) JJA, and (d) SON.
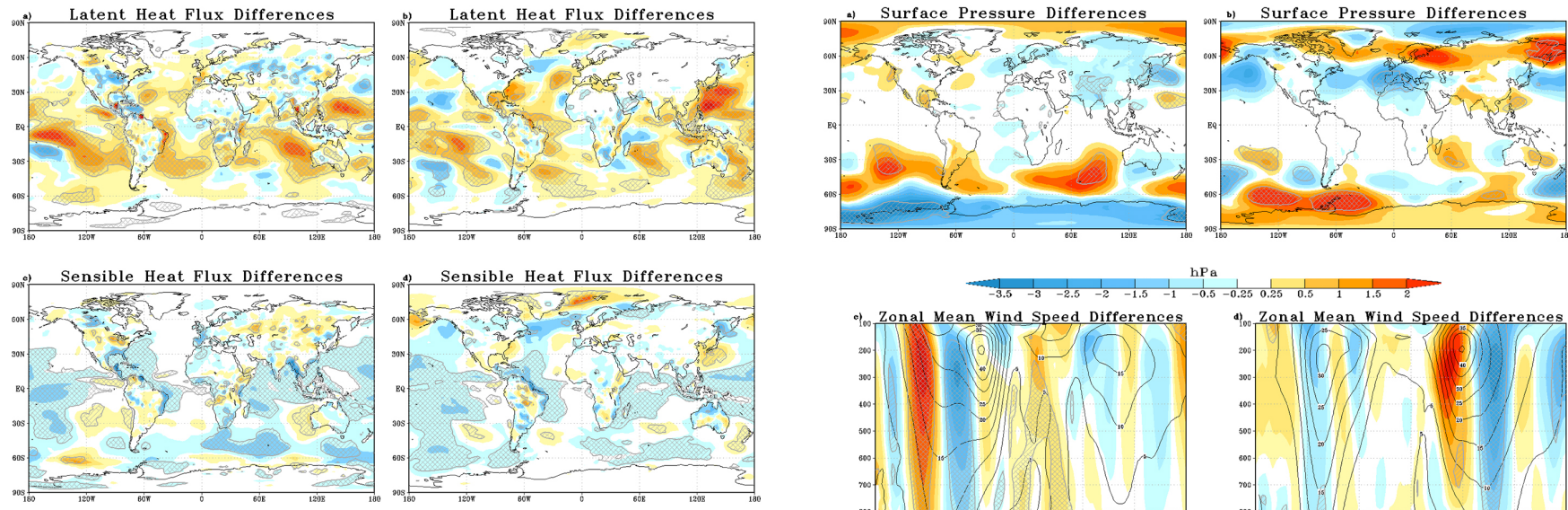

W

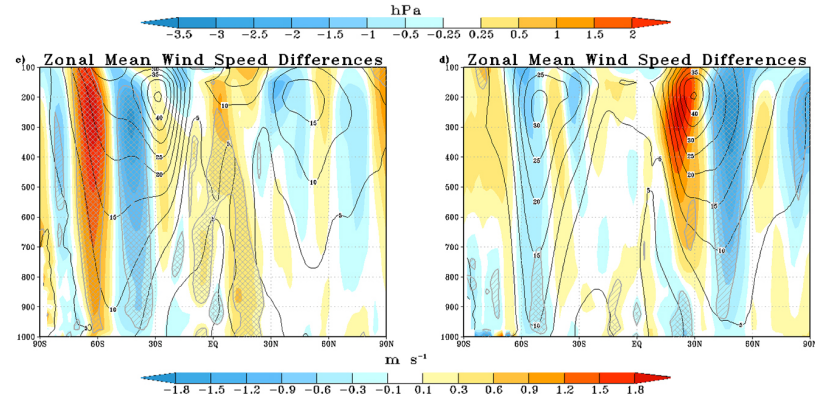

Figure 6. Seasonal mean latent heat flux differences (Method 3 minus Method 2) for JJA (a) and DJF (b) and seasonal mean sensible heat flux differences for JJA (c) and DJF (d). Hatch marks represent significance at the $90 \%$ level using the Student's $t$ test. Crosshatch marks represent significance at the $95 \%$ level.

Figure 7. Seasonal mean surface pressure differences (Method 3 minus Method 2) for JJA (a) and DJF (b) and zonal mean, seasonal mean wind speed differences (shaded), and $K_{\mathrm{h}}: 10 \%$ method wind speeds (contours) for JJA (c) and DJF (d). Hatch marks represent significance at the $90 \%$ level using the Student's $t$ test. Crosshatch marks represent significance at the $95 \%$ level. 

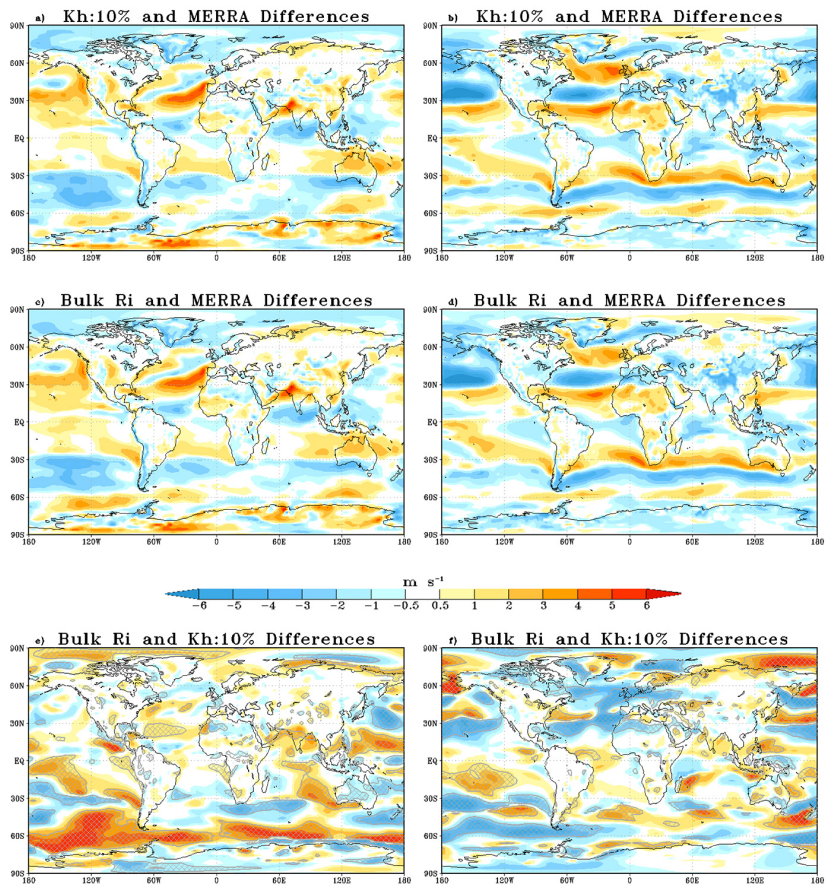

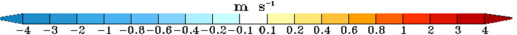

Figure 8. Seasonal mean $10 \mathrm{~m}$ wind speed differences. Method 2 minus MERRA for JJA (a) and DJF (b), Method 3 minus MERRA for JJA (c) and DJF (d), and Method 3 minus Method 2 for JJA (e) and DJF (f). Hatch marks on the bottom plots represent significance at the $90 \%$ level using the Student's $t$ test. Crosshatch marks represent significance at the $95 \%$ level.

ity differences are positively correlated with changes in soil moisture and a shift in the Bowen ratio with more latent heat flux in the bulk $R i$ experiment.

Generally, experiment 3 (bulk $R i$ ) predicts more marine low-level clouds than experiment 2 does $\left(K_{\mathrm{h}}: 10 \%\right)$ (Fig. 11). The overall increase in low-level clouds is associated with an increase in latent heat flux over the oceans due, in part, to the increase in the low-level wind speeds. The increase is particularly evident south of $30^{\circ} \mathrm{S}$, over the subtropical Atlantic, and off the west coast of North America during DJF and the west coast of South America in both seasons. In comparison to the ISCCP climatology, experiment 3 better predicts cloud cover over most of the area between $30^{\circ} \mathrm{N}$ and $30^{\circ} \mathrm{S}$ but is worse in the extratropics.

An increase in low-level clouds produces increases in downward long-wave radiation and higher PBL temperature, modifying the thermodynamic profile. This can lead to enhanced turbulence and mixing due to reduced stability and produce a feedback on boundary layer growth.

In summary, changes in PBL depth, specifically lower PBL depths over land due to lower nocturnal PBL depths and greater depths over oceans when using Method 3, lead to complex interactions between PBL processes. Differences in
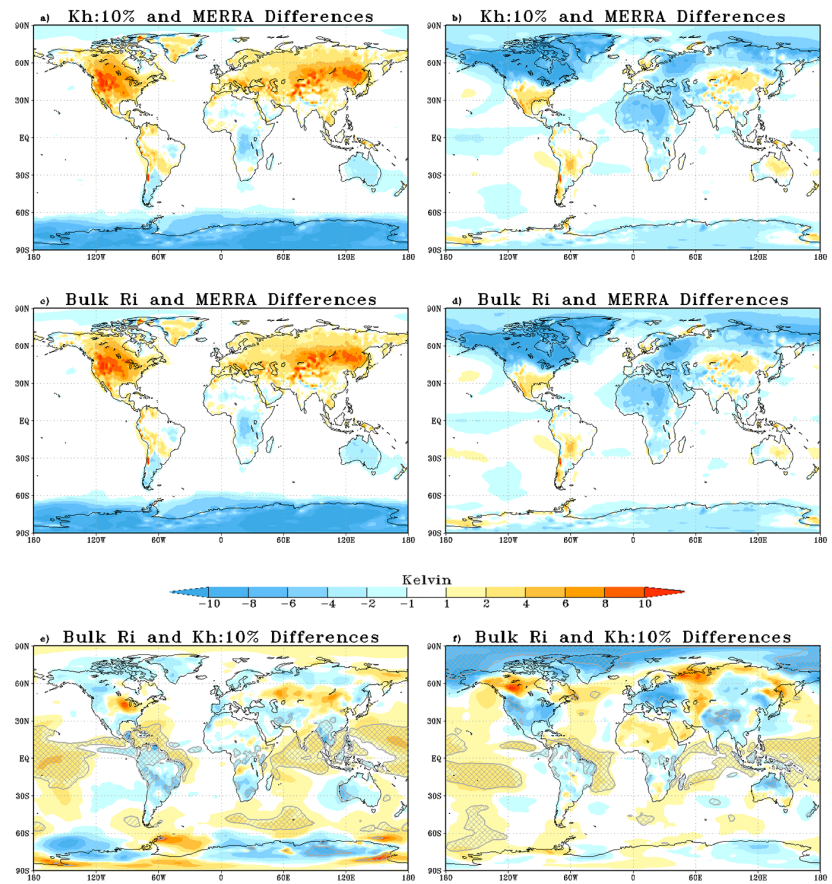

Kelvin

Figure 9. Seasonal mean $2 \mathrm{~m}$ temperature differences. Method 2 minus MERRA for JJA (a) and DJF (b), Method 3 minus MERRA for JJA (c) and DJF (d), and Method 3 minus Method 2 for JJA (e) and DJF (f). Hatch marks on the bottom plots represent significance at the $90 \%$ level using the Student's t test. Crosshatch marks represent significance at the $95 \%$ level.

turbulent mixing result in differences in the mean circulation and this redistribution of mass leads to changes in temperature, specific humidity, and wind velocity and consequently to changes in cloud cover.

\section{Impact on tracer transport}

Modifications to the model climate result in changes to trace gas and aerosol transport and concentrations. Some species are directly dependent on the model climate for their emissions and all tracers are subject to changes in turbulent mixing and horizontal advection. Atmospheric dust concentrations are particularly sensitive to PBL depth estimates because their emission is sensitive to wind speed, and the height to which they are mixed vertically in the atmosphere depends on the turbulence determined, in part, by the PBL depth. This is significant for deposition and settling of the dust particles. Another consequence for the chemical composition of the atmosphere is that the PBL depth in the GEOS-5 AGCM determines the depth to which biomass burning emissions are homogeneously emitted, meaning that, over fires, shallower PBLs result in a higher near-surface concentration of chemical species like carbon monoxide. This has implica- 

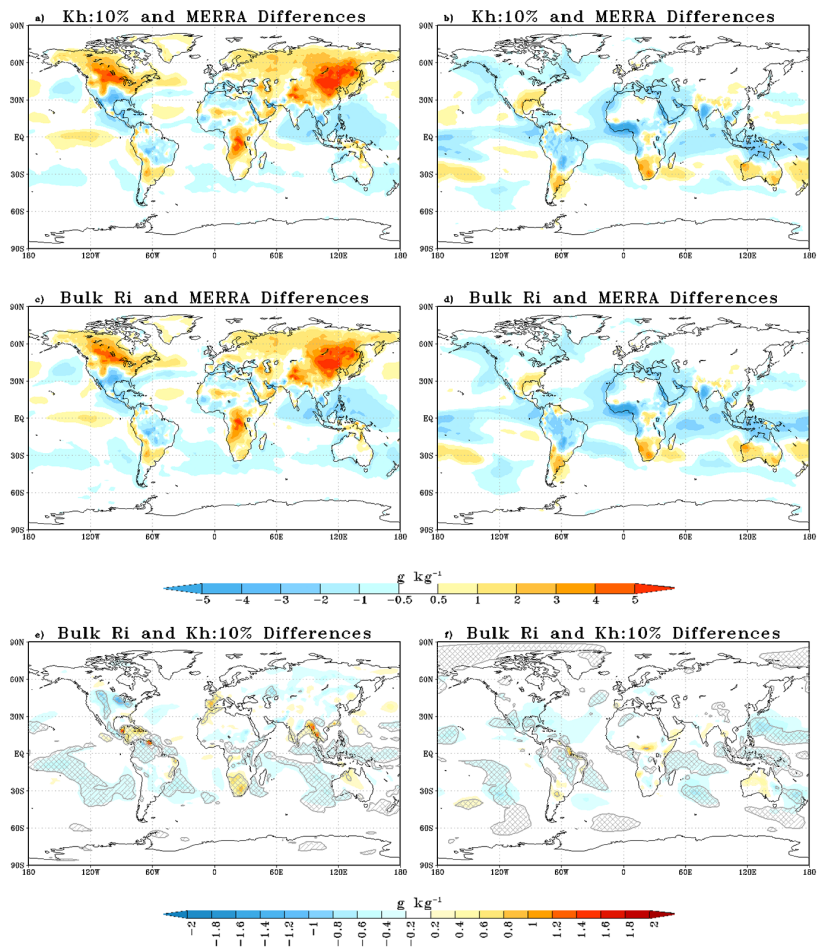

Figure 10. Seasonal mean $2 \mathrm{~m}$ specific humidity differences. Method 2 minus MERRA for JJA (a) and DJF (b), Method 3 minus MERRA for JJA (c) and DJF (d), and Method 3 minus Method 2 for JJA (e) and DJF (f). Hatch marks on the bottom plots represent significance at the $90 \%$ level using the Student's $t$ test. Crosshatch marks represent significance at the $95 \%$ level.

tions for chemical processes dependent on the availability of these species.

Figure 12 shows aerosol optical thickness from the MODIS and MISR instruments compared to that simulated by the model using the two PBL depth definitions. Qualitatively, the results are similar among the model simulations and the observations. The highest AOT is present over the Sahara and the dust outflow region over the Atlantic Ocean. Other maxima exist near biomass burning and industrial areas. The lowest simulated AOT occurs over the high latitudes, which the satellites do not observe. The model estimates a higher AOT than the satellite observations due partially to the inability of the satellites to observe all locations. Mean AOT values observed by MODIS/Terra, MODIS/Aqua, and MISR are 0.1277, 0.1339, and 0.1808, respectively. MISR detects a higher AOT value because it is able to sense aerosols over reflective surfaces and therefore is able to observe over the Sahara. The model simulations estimate AOT values of 0.1943 and 0.2153 for the $K_{\mathrm{h}}: 10 \%$ and bulk $R i$ experiments, respectively. Overall, the model is able to represent the observed AOT reasonably well.

Due to its dependence on surface winds, the emission of Saharan dust (Fig. 13) is increased in experiment 3 (bulk $R i$ )
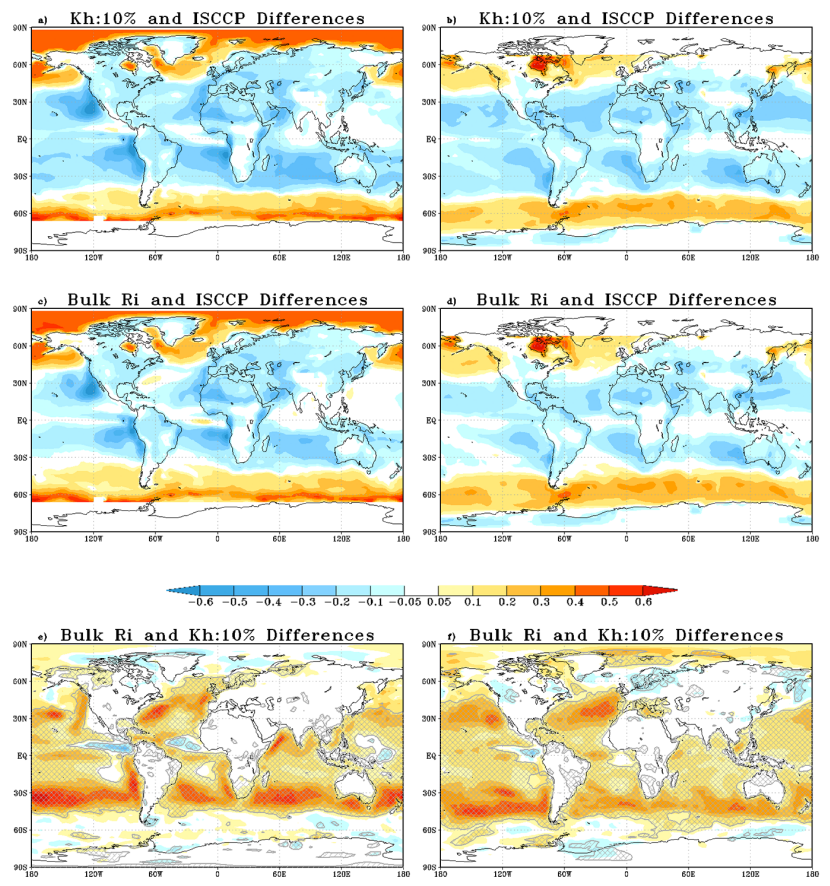

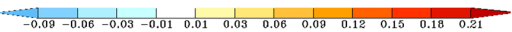

Figure 11. Seasonal mean low-level cloud fraction differences. Method 2 minus ISCCP for JJA (a) and DJF (b), Method 3 minus ISCCP for JJA (c) and DJF (d), and Method 3 minus Method 2 for JJA (e) and DJF (f). Hatch marks on the bottom plots represent significance at the $90 \%$ level using the Student's $t$ test. Crosshatch marks represent significance at the $95 \%$ level.

during JJA, consistent with the increased wind speed in this experiment. One of the major mechanisms of transporting tracers from the boundary layer to the free troposphere is turbulent mixing associated with the boundary layer collapse during the evening transition (Donnell et al., 2001). Since experiment 3 (bulk $R i$ ) simulates a stronger evening collapse than the other experiments (Fig. 1), it is expected that more dust is transported to the free troposphere in this experiment. Once lofted to the free troposphere, dust generally experiences a longer lifetime and a greater chance for long-range transport downwind from the source region.

Figure 14 shows the global impact of these changes on the total column dust concentration. Globally, percentage differences range from 0 to $50 \%$. The largest significant changes are over the Sahara and downwind over the Atlantic Ocean. Increased Saharan dust emissions and turbulent mixing to the free troposphere produce an increase in atmospheric dust that is then transported downwind, mostly between 800 and $500 \mathrm{hPa}$ (Fig. 15), to the Caribbean and North America, increasing column concentrations there. Although column concentrations are increased in the western Atlantic, surface concentrations actually decrease in experiment 3 . Increased dust aloft increases the shortwave radiation temperature tendency 

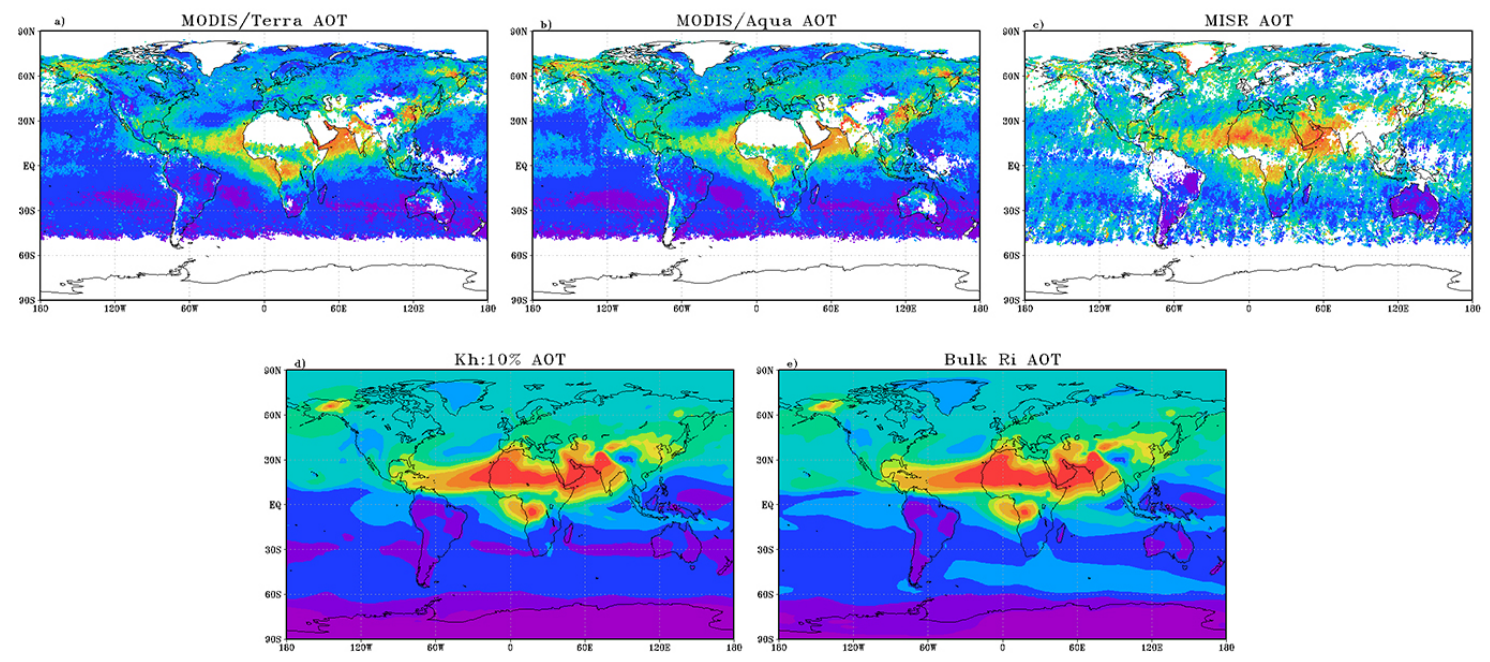

$\begin{array}{lllllllllll}0.02 & 0.05 & 0.1 & 0.15 & 0.2 & 0.3 & 0.4 & 0.5 & 0.7 & 1 & 6.1\end{array}$

Figure 12. July 2009 monthly mean aerosol optical thickness observations from the MODIS instruments on the Terra (global mean $=0.1277$, standard deviation $=0.0645 ; \mathbf{a}$ ) and Aqua (global mean $=0.1339$, standard deviation $=0.0750 ;$ b) satellites and from the MISR (global mean $=0.1808$, standard deviation $=0.0617 ; \mathbf{c}$ ) instrument on Terra. Monthly average aerosol optical thickness simulated by the GEOS5 model using the turbulent eddy diffusion coefficient method and a threshold of $10 \%$ of the column maximum (Method 2, global mean $=0.1943$, standard deviation $=0.0774 ; \mathbf{d})$ and the bulk Richardson number method (Method 3, global mean $=0.2153$, standard deviation $=0.0880 ; \mathbf{e})$.
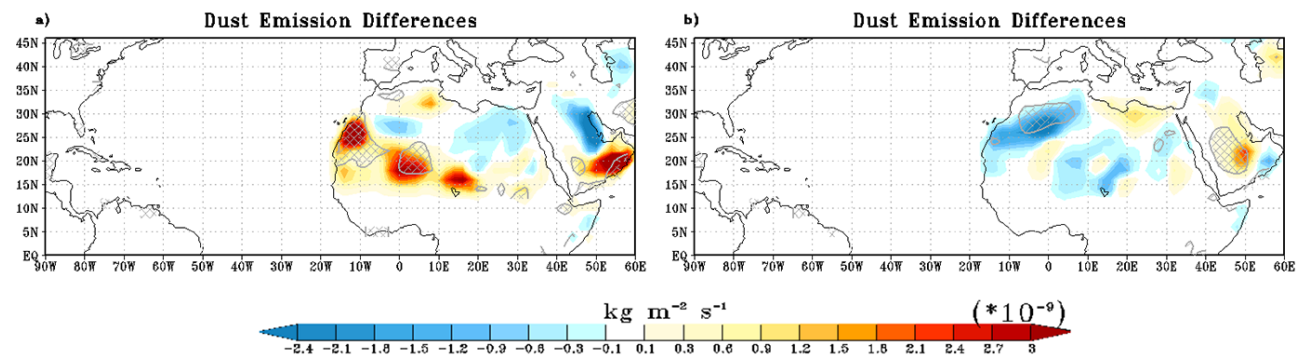

Figure 13. Seasonal mean dust emission differences (Method 3 minus Method 2) for JJA (a) and DJF (b). Average dust emission in the emitting region is about $1 \times 10^{-8} \mathrm{~kg} \mathrm{~m}^{-2} \mathrm{~s}^{-1}$. Hatch marks represent significance at the $90 \%$ level using the Student's $t$ test. Crosshatch marks represent significance at the $95 \%$ level.

due to aerosols producing warmer temperatures there and shading the lower atmosphere (and decreasing the shortwave radiation temperature tendency due to aerosols), thus producing cooling near the surface (not shown). This creates an increase in lower tropospheric stability and acts to reduce the turbulent mixing of dust downward. Modifications to the thermodynamic profiles due to the redistribution of dust thus contribute to the differences in turbulence.

During DJF, the opposite impact is seen over the Sahara. Surface winds decrease in experiment 3 (bulk $R i$ ), leading to a decrease in desert dust emissions there (Fig. 13). This, in turn, leads to a decrease in the column dust concentrations over northwestern Africa and downwind over the subtropical Atlantic Ocean. The impact does not extend as far downwind during DJF as it does during JJA, due in part to the more southerly location of the easterly jet. Over the Arabian Peninsula, experiment 3 (bulk $R i$ ) winds are greater than in experiment $2\left(K_{\mathrm{h}}: 10 \%\right)$, leading to increased desert dust emissions and increased column concentrations that extend to the northwest into central Asia.

In both seasons, the free-running model overestimates column dust concentrations over northern Africa and downwind across the Atlantic compared to MERRAero. Therefore, the reduction in column dust is an improvement over northwestern Africa in DJF and the increase during JJA is a degradation. This is despite an indication from McGrath-Spangler and Molod (2014) that the bulk Richardson-number-based definition better represents the nocturnal PBL depth over the Sahara than the scalar-diffusivity-based ones. 

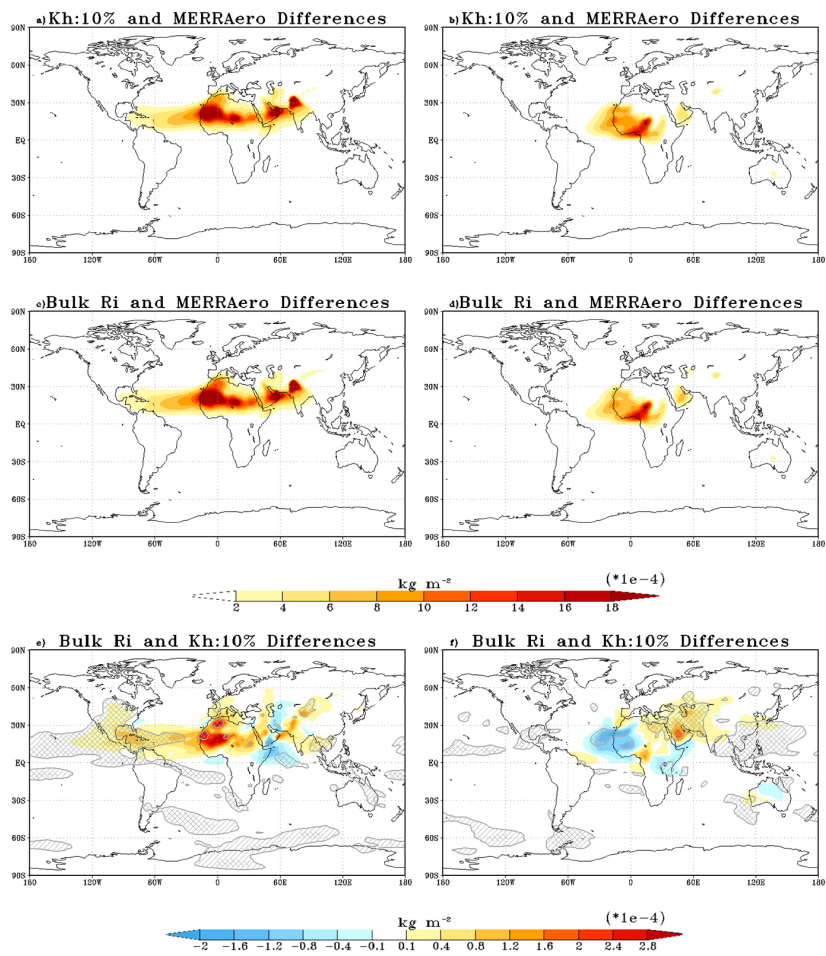

Figure 14. Seasonal mean column dust differences. Method 2 minus MERRAero for JJA (a) and DJF (b), Method 3 minus MERRAero for JJA (c) and DJF (d), and Method 3 minus Method 2 for JJA (e) and DJF (f). Global mean column dust concentrations in the free-running models is about $1.2 \times 10^{-4} \mathrm{~kg} \mathrm{~m}^{-2}$ during JJA and about $5.7 \times 10^{-5} \mathrm{~kg} \mathrm{~m}^{-2}$ during DJF. Hatch marks on the bottom plots represent significance at the $90 \%$ level using the Student's $t$ test. Crosshatch marks represent significance at the $95 \%$ level.

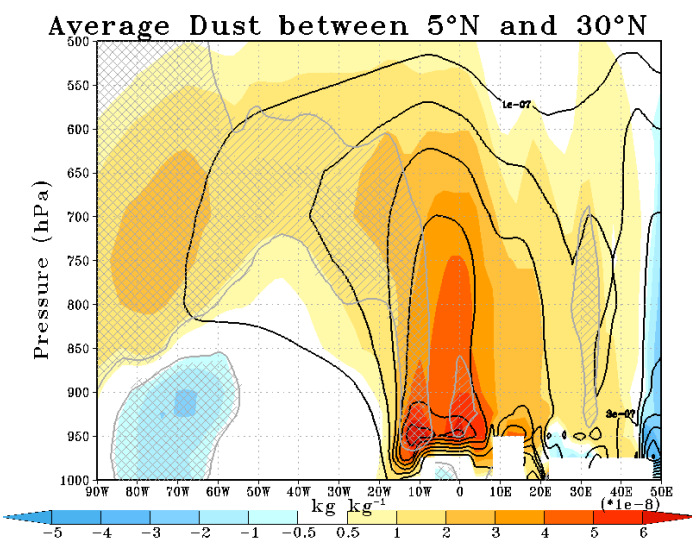

Figure 15. Seasonal mean dust differences (shaded, Method 3 minus Method 2) and mean dust concentration (black contours) for JJA averaged from 5 to $30^{\circ} \mathrm{N}$. Average concentration is about $1.6 \times 10^{-7} \mathrm{~kg} \mathrm{~kg}^{-1}$. Hatch marks represent significance at the $90 \%$ level using the Student's $t$ test. Crosshatch marks represent significance at the $95 \%$ level.
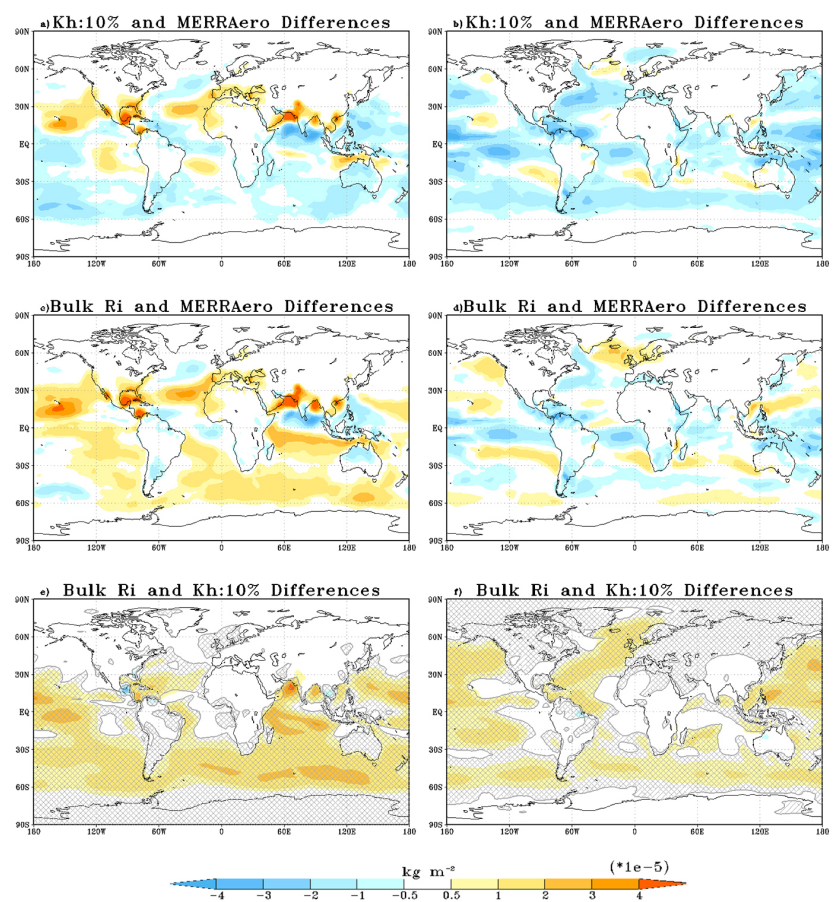

Figure 16. Seasonal mean column sea salt differences. Method 2 minus MERRAero for JJA (a) and DJF (b), Method 3 minus MERRAero for JJA (c) and DJF (d), and Method 3 minus Method 2 for JJA (e) and DJF (f). Hatch marks on the bottom plots represent significance at the $90 \%$ level using the Student's $t$ test. Crosshatch marks represent significance at the $95 \%$ level.

The amount of sea salt aerosol in the atmospheric column (Fig. 16) is generally greater in experiment 3 (bulk $R i$ ) due to an overall increase in wind speed over the oceans used to estimate sea salt emission into the atmosphere. Although experiment 3 is able to produce a similar pattern as MERRAero, the free-running model overestimates the sea salt concentration and experiment 2 performs better.

In the GEOS-5 AGCM, biomass burning emissions are instantaneously mixed vertically throughout the PBL so surface concentrations of $\mathrm{CO}$ from fires are inversely related to the depth of the PBL. Surface CO patterns in the model and MOPITT observations are generally consistent (Fig. 17). In general, biomass burning emissions over Africa are further north in DJF than in JJA, and the seasonality is properly captured in all model simulations. Surface CO concentrations over the industrial cities of China increase during DJF (MOPITT estimates about $350 \mathrm{ppb}$ ) relative to JJA (MOPITT estimates about $250 \mathrm{ppb}$ ), associated with lower PBL depths during the winter.

During JJA, the largest $\mathrm{CO}$ concentration differences between experiments 2 and $3\left(K_{\mathrm{h}}: 10 \%\right.$ and bulk $\left.R i\right)$ are present over the biomass burning regions experiencing variations in PBL depth (MOPITT estimates about 100-300 ppb), specifically over the African continent. Over South Africa, the PBL depth estimated by Method 3 is about $1 \mathrm{~km}$ lower than in the 

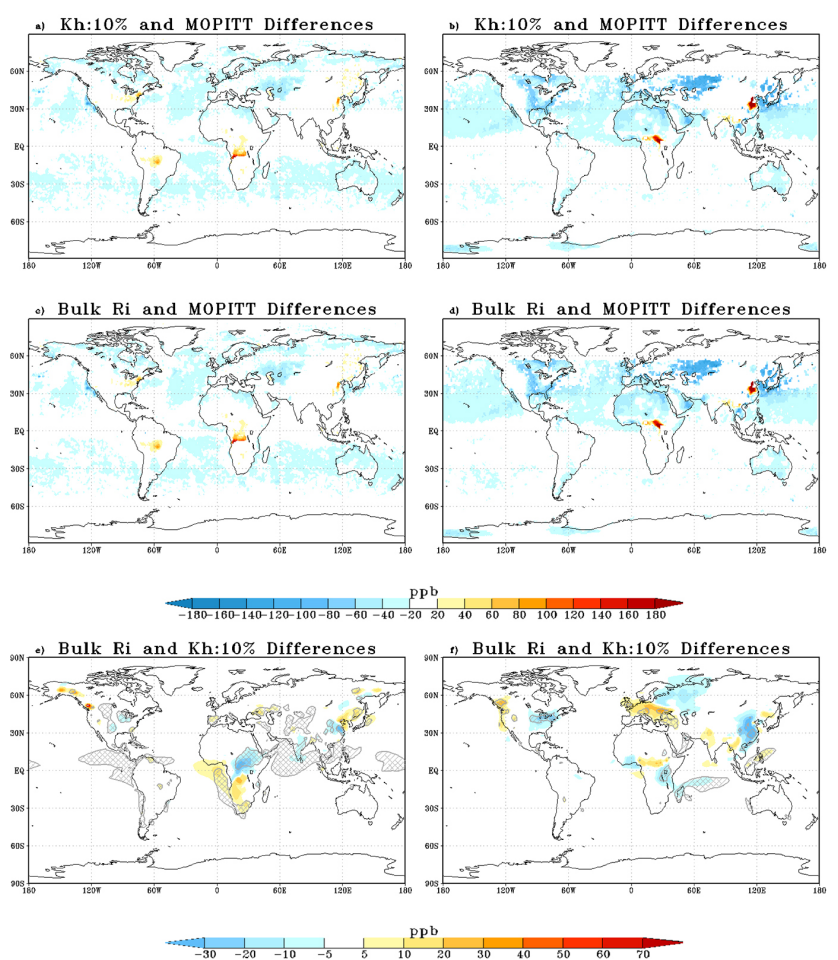

Figure 17. Seasonal mean surface $\mathrm{CO}$ differences. Method 2 minus MOPITT for JJA (a) and DJF (b), Method 3 minus MOPITT for JJA (c) and DJF (d), and Method 3 minus Method 2 for JJA (e) and DJF (f). Model comparisons to MOPITT have been sampled using the MOPITT averaging kernel. Hatch marks on the bottom plots represent significance at the $90 \%$ level using the Student's $t$ test. Crosshatch marks represent significance at the $95 \%$ level.

scalar diffusion coefficient method, concentrating $\mathrm{CO}$ near the surface. The decrease over Ethiopia and Sudan in experiment 3 is due to an increased daytime PBL depth diluting $\mathrm{CO}$ emissions and leading to lowered surface concentrations. These $\mathrm{CO}$ differences are an improvement relative to MOPITT observations.

During DJF, surface CO differences over Africa are much smaller, however, significant decreases in surface $\mathrm{CO}$ are present over eastern China and the Great Lakes region of the United States in experiment 3 associated with differences in PBL depth. These regions have daytime PBL depths estimated by the bulk Richardson number that are greater than those in the other experiment, and the associated increase in vertical mixing leads to a decrease in surface $\mathrm{CO}$ concentrations. Differences in CO extend vertically through the atmosphere, leading to differences at $500 \mathrm{hPa}$ of up to $18 \mathrm{ppb}$ (not shown). These free-tropospheric differences affect the horizontal transport of $\mathrm{CO}$ over long distances.

Figure 18 shows the column $\mathrm{CO}_{2}$ differences among experiments 2 and $3\left(K_{\mathrm{h}}: 10 \%\right.$ and bulk $\left.R i\right)$ and the ACOS retrieval from GOSAT. In general, the model overestimates column $\mathrm{CO}_{2}$ over extratropical land compared to the ob-
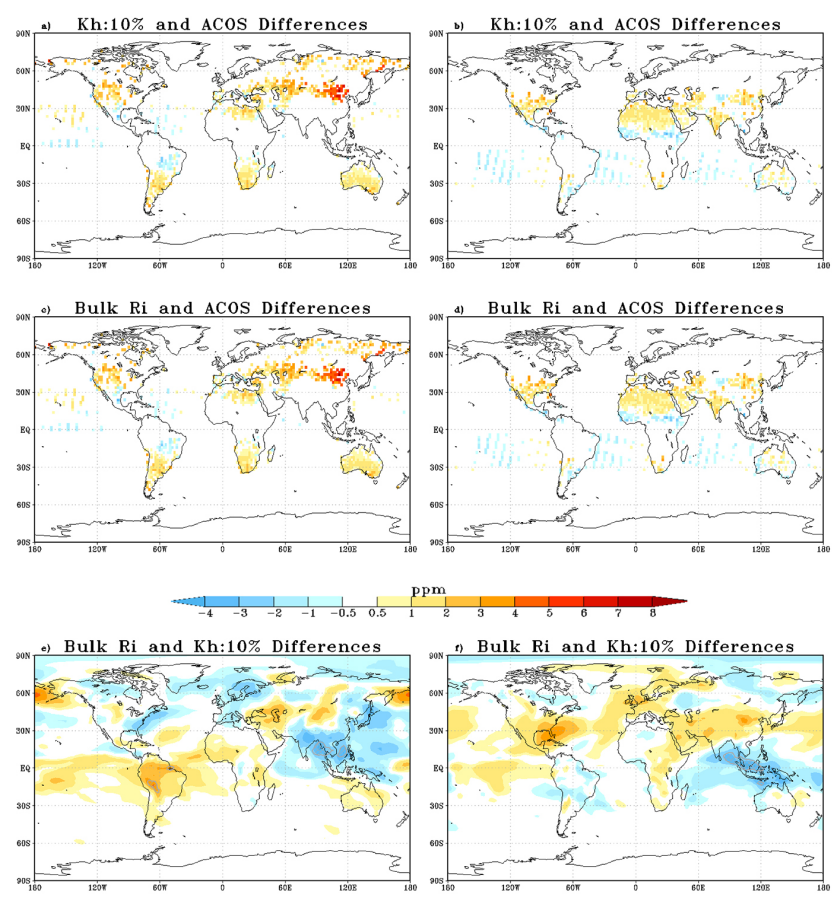

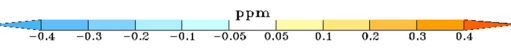

Figure 18. Seasonal mean column $\mathrm{CO}_{2}$ differences. Method 2 minus ACOS for JJA (a) and DJF (b), Method 3 minus ACOS for JJA (c) and DJF (d), and Method 3 minus Method 2 for JJA (e) and DJF (f). Model comparisons to ACOS have been sampled using the ACOS averaging kernel. Hatch marks on the bottom plots represent significance at the $90 \%$ level using the Student's $t$ test. Crosshatch marks represent significance at the $95 \%$ level.

servations. However, time mean differences between experiments 2 and 3 are only significant over small regions in the tropics where there are no ACOS retrievals. In most regions, the differences do not exceed the internal model variability.

Figure 19 shows the impact of PBL depth definition on the surface $\mathrm{CO}_{2}$ concentration. These differences are due to changes in the dilution of surface fluxes. In JJA, there are large regions of $\mathrm{CO}_{2}$ differences over the tropical oceans, where experiment 3 simulates $\mathrm{CO}_{2}$ concentrations about $1 \mathrm{ppm}$ lower than experiment 2 . This occurs in regions with increased PBL depths diluting oceanic emissions of $\mathrm{CO}_{2}$ thereby decreasing the surface concentration. Seasonal mean increase in $\mathrm{CO}_{2}$ over central South America is associated with nocturnal PBLs in experiment $31 \mathrm{~km}$ lower than in experiment 2, concentrating nighttime $\mathrm{CO}_{2}$ respiration emissions and increasing surface concentrations there.

The largest seasonal mean $\mathrm{CO}_{2}$ differences occur during DJF. Over western North America, experiment 3 (bulk $R i$ ) estimates $\mathrm{CO}_{2}$ concentrations about $3 \mathrm{ppm}$ greater than in experiment $2\left(K_{\mathrm{h}}: 10 \%\right)$. Experiment 3 estimates shallower PBLs throughout the diurnal cycle, producing a concentration of $\mathrm{CO}_{2}$ emissions and higher concentrations. 

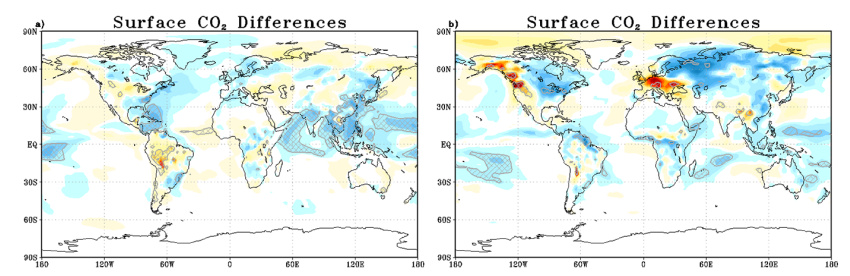

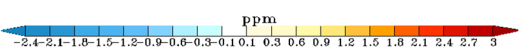

Figure 19. Seasonal mean surface $\mathrm{CO}_{2}$ differences (Method 3 minus Method 2) for JJA (a) and DJF (b). Hatch marks represent significance at the $90 \%$ level using the Student's $t$ test. Crosshatch marks represent significance at the $95 \%$ level.

Regions with persistent and significant surface $\mathrm{CO}_{2}$ biases due to PBL depth changes are small. This is partly because synoptic variability can produce $\mathrm{CO}_{2}$ variations on the order of 10-20 ppm that are averaged out in the time mean (Parazoo et al., 2008). Figure 20 shows an example of surface $\mathrm{CO}_{2}$ differences between experiments 2 and 3 at specific times during JJA and DJF. On these smaller timescales, surface $\mathrm{CO}_{2}$ differences are much larger than in the time mean, on the order of $10 \mathrm{ppm}$, and these differences are significant globally. This is especially true during DJF at middle and high northern latitudes where differences are often on the order of $15 \mathrm{ppm}$ and are advected along with synoptic storms. Figure 20 also shows the standard deviation of surface $\mathrm{CO}_{2}$ differences for July and January. The greatest variability is present during January over high-latitude land with standard deviations exceeding $7 \mathrm{ppm}$ over parts of Asia. Generally, variability is high over land in both seasons. This has implications for inversion studies that often assume perfect transport. Uncertainty in estimated $\mathrm{CO}_{2}$ concentrations may be incorrectly attributed to surface fluxes rather than errors in assumed vertical transport.

\section{Conclusions}

Weather, climate, and tracer transport and concentrations are sensitive to PBL processes. One way to quantify these processes is with the depth of the PBL. However, multiple PBL depth definitions exist and these estimated depths can vary substantially even when defined using the same atmospheric profile (Seidel et al., 2012; McGrath-Spangler and Molod, 2014). In the GEOS-5 AGCM, the PBL depth is used to calculate the turbulent length scale that is used to estimate the model turbulence at the next time step, making it important to properly estimate this depth and be cognizant of the process interactions affecting the simulated global weather and climate.

This study analyzed three PBL depth definitions. Two are based on the turbulent eddy diffusion coefficient and use threshold values of $2 \mathrm{~m}^{2} \mathrm{~s}^{-1}\left(K_{\mathrm{h}}: 2\right.$, Method 1) and $10 \%$ of the column maximum $\left(K_{\mathrm{h}}: 10 \%\right.$, Method 2$)$. The third
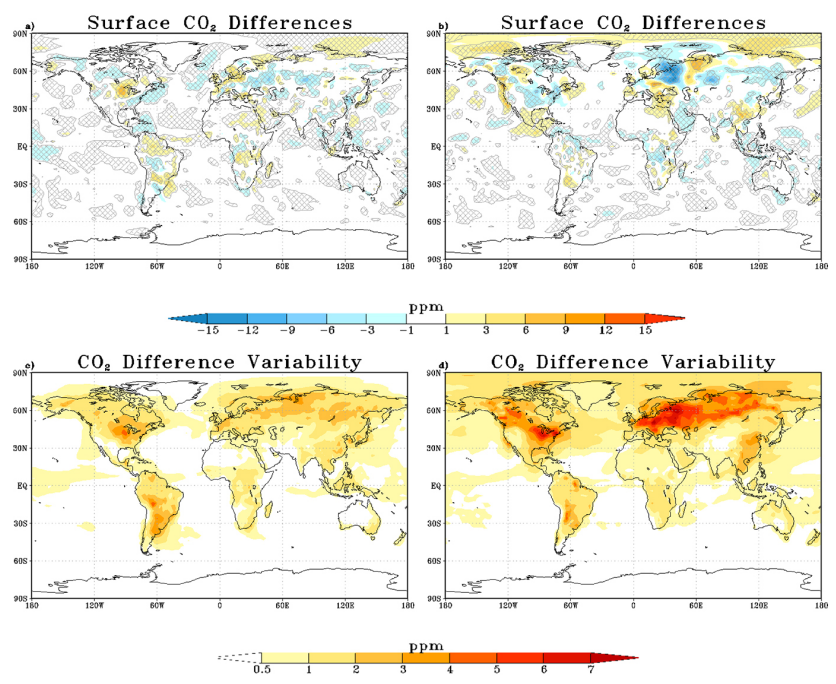

Figure 20. Surface $\mathrm{CO}_{2}$ differences (Method 3 minus Method 2) for (a) 1:30Z 1 July 2009 and (b) 1:30Z 1 January 2010. Hatch marks represent significance at the $90 \%$ level using the Student's $t$ test. Crosshatch marks represent significance at the $95 \%$ level. Standard deviation of surface $\mathrm{CO}_{2}$ differences (Method 3 minus Method 2) for (c) July 2009 and (d) January 2010.

method uses the bulk Richardson number definition (bulk $R i$, Method 3) described by Seidel et al. (2012). Ten ensemble members were run for each of these definitions and comparisons were made between the ensemble means. The bulk $R i$ ensemble (experiment 3 ) generally estimated a lower PBL depth over land due to lower nocturnal PBL depths. This is consistent with the result of McGrath-Spangler and Molod (2014), who diagnosed several PBL depths from a single atmosphere using various definitions.

The different PBL depth definitions, when used to inform the turbulent length scale in the model, resulted in a largescale climatic response. The response was characterized by a redistribution of atmospheric mass and subsequent changes in winds. During JJA in experiment 3, increased wind speed over the Sahara resulted in increased dust emissions and column dust concentrations over the desert and downwind over the Atlantic Ocean. The near-surface temperature and specific humidity were also modified in experiment 3 resulting in improvements in temperature over much of the land surface.

In addition to dust, other tracers were impacted by changes in the PBL depth definition. Dilution of CO from biomass burning emissions by the PBL depth results in variations in surface concentrations with greater depths producing lower values. In these conditions, experiment 3 produced the best results when compared to MOPITT observations.

Differences between the simulations' $\mathrm{CO}_{2}$ estimates were most significant near the surface and in instantaneous fields. Time mean differences are generally not significant and small (on the order of a few ppm); however, differences at shorter 
timescales are globally significant and large (on the order of $10 \mathrm{ppm}$ ), especially during DJF at high northern latitudes when synoptic systems are most prevalent.

PBL depth differences between the model simulations occur due to methodological differences and inconsistencies between the depth of the turbulent layer as defined by the turbulent eddy diffusion coefficient and the unstable layer as defined by the bulk Richardson number. These differences have consequences for land-atmosphere interactions, radiation, and atmospheric chemistry because of impacts on the vertical extent of turbulent mixing. It is therefore important to carefully consider the impact on model climate and tracer concentrations when modifying the simulated PBL depth in GEOS-5. While the bulk $R i$ experiment generally predicts a more reasonable diurnal cycle of PBL depth, other aspects of the simulation are not universally improved.

The importance of lower tropospheric mixing to estimates of and model sensitivity to global climate change has recently been evaluated (Sherwood et al., 2014). Changing the PBL depth definition used to calculate the turbulent length scale in GEOS-5 is one of many ways of affecting low-level mixing and the results presented here show the sensitivity of model processes. The PBL depth, however, is a unique indicator of the strength of vertical mixing in the lower troposphere and can be used to compare model simulations to observational estimates from the international network of radiosondes, wind profilers, lidars, etc. In addition to its impact on turbulent mixing and significance for global climate, the PBL depth is inherently significant to studies addressing aerosol and greenhouse gas transport and concentrations. Furthermore, in GEOS-5, the PBL depth is used to estimate the vertical distribution of biomass burning emissions and is therefore essential to the correct simulation of biomass burning concentrations and transport.

Only 1 year is simulated and the free-running AGCM does not simulate any specific weather event, limiting direct comparisons to observations. Future research should include long-term climatological simulations that estimate the impact of PBL depth on GEOS-5 model climate and further isolate the climatic response to PBL depth definition from internal model variability. The GEOS-5 AGCM is sensitive to the estimated PBL depth and the definition used can affect model climate and the estimated distribution of greenhouse gases and atmospheric aerosols relevant for climate and air quality research.

Acknowledgements. The authors thank two anonymous reviewers. The MERRA data are produced by the NASA Global Modeling and Assimilation Office and disseminated by the GES DISC. The ACOS data were produced by the ACOS/OCO-2 project at the Jet Propulsion Laboratory, California Institute of Technology, using spectra data acquired by the GOSAT Project. We would like to acknowledge the NASA Langley Research Center Atmospheric Science Data Center for disseminating the MOPITT and ISCCP data, the Goddard DAAC and MODIS software development and support teams for providing the MODIS data, and the MISR retrieval team. Computing was supported by the NASA Center for Climate Simulation. The research was supported by National Aeronautics and Space Administration grant NNG11HP16A.

Edited by: M. Van Roozendael

\section{References}

Bacmeister, J. T., Suarez, M. J., and Robertson, F. R.: Rain Reevaporation, Boundary Layer-Convection Interactions, and Pacific Rainfall Patterns in an AGCM, J. Atmos. Sci., 63, 3383-3403, doi:10.1175/jas3791.1, 2006.

Baker, D. F., Law, R. M., Gurney, K. R., Rayner, P., Peylin, P., Denning, A. S., Bousquet, P., Bruhwiler, L., Chen, Y.-H., Ciais, P., Fung, I. Y., Heimann, M., John, J., Maki, T., Maksyutov, S., Masaarie, K., Prather, M., Pak, B., Taguchi, S., and Zhu, Z.: TransCom 3 inversion intercomparison: Impact of transport model errors on the interannual variability of regional $\mathrm{CO}_{2}$ fluxes, 1988-2003, Global Biogeochem. Cy., 20, GB1002, doi:10.1029/2004GB002439, 2006

Balkanski, Y., Schulz, M., Claquin, T., and Guibert, S.: Reevaluation of Mineral aerosol radiative forcings suggests a better agreement with satellite and AERONET data, Atmos. Chem. Phys., 7, 81-95, doi:10.5194/acp-7-81-2007, 2007.

Ballard, S. P., Golding, B. W., and Smith, R. N. B.: Mesoscale model experimental forecasts of the Haar of northeast Scotland, Mon. Weather Rev., 119, 2107-2123, doi:10.1175/15200493(1991)119<2107:MMEFOT>2.0.CO;2, 1991.

Beljaars, A. C. M. and Betts, A. K.: Validation of the boundary layer representation in the ECMWF model, ECMWF Seminar Proceedings, Reading, UK, 7-11 September 1992, Validation of models over Europe, Vol. II, 159-195, available at: http://old.ecmwf.int/publications/library/ecpublications/_pdf/ seminar/1992/validation2_beljaars.pdf (last access: 24 October 2014), 1992.

Blackadar, A. K.: The vertical distribution of wind and turbulent exchange in a neutral atmosphere, J. Geophys. Res., 67, 30953102, doi:10.1029/JZ067i008p03095, 1962.

Chin, M., Ginoux, P., Kinne, S., Torres, O., Holben, B. N., Duncan, B. N., Martin, R. V., Logan, J. A., Higurashi, A., and Nakajima, T.: Tropospheric aerosol optical thickness from the GOCART model and comparisons with satellite and sunphotometer measurements, J. Atmos. Sci., 59, 461-483, doi:10.1175/15200469(2002)059<0461:TAOTFT>2.0.CO;2, 2002.

Chin, M., Ginoux, P., Lucchesi, R., Huebert, B., Weber, R., Anderson, T., Masonis, S., Blomquist, B., Bandy, A., and Thornton, D.: A global aerosol model forecast for the ACE-Asia field experiment, J. Geophys. Res., 108, 8654, doi:10.1029/2003JD003642, 2003.

Chou, M.-D. and Suarez, M. J.: A solar radiation parameterization for atmospheric studies, Technical Report Series on Global Modeling and Data Assimilation, 40 pp., available at: http://gmao.gsfc.nasa.gov/pubs/docs/Chou136.pdf (last access: 4 March 2014), 1999.

Chou, M.-D., Suarez, M. J., Liang, X.-Z., and Yan, M. M.-H.: A thermal infrared radiation parameterization for atmospheric studies, Technical Report Series on Global Modeling and Data As- 
similation, 56 pp., available at: http://gmao.gsfc.nasa.gov/pubs/ tm/docs/Chou137.pdf (last access: 4 March 2014), 2001.

Colarco, P. R., Nowottnick, E. P., Randles, C. A., Yi, B., Yang, P., Kim, K.-M., Smith, J. A., and Bardeen, C. G.: Impact of radiatively interactive dust aerosols in the NASA GEOS-5 climate model: Sensitivity to dust particle shape and refractive index, J. Geophys. Res.-Atmos., 119, 753-786, doi:10.1002/2013JD020046, 2014.

Conway, T. J., Tans, P. P., Waterman, L. S., Thoning, K. W., Kitzis, D. R., Masarie, K. A., and Zhang, N: Evidence for interannual variability of the carbon cycle from the National Oceanic and Atmospheric Administration/Climate Monitoring and Diagnostics Laboratory Global Air Sampling Network, J. Geophys. Res., 99, 22831-22855, doi:10.1029/94JD01951, 1994.

Crisp, D., Fisher, B. M., O’Dell, C., Frankenberg, C., Basilio, R., Bösch, H., Brown, L. R., Castano, R., Connor, B., Deutscher, N. M., Eldering, A., Griffith, D., Gunson, M., Kuze, A., Mandrake, L., McDuffie, J., Messerschmidt, J., Miller, C. E., Morino, I., Natraj, V., Notholt, J., O'Brien, D. M., Oyafuso, F., Polonsky, I., Robinson, J., Salawitch, R., Sherlock, V., Smyth, M., Suto, H., Taylor, T. E., Thompson, D. R., Wennberg, P. O., Wunch, D., and Yung, Y. L.: The ACOS $\mathrm{CO}_{2}$ retrieval algorithm - Part II: Global $X_{\mathrm{CO}_{2}}$ data characterization, Atmos. Meas. Tech., 5, 687707, doi:10.5194/amt-5-687-2012, 2012.

Darmenov, A. S. and da Silva, A.: The Quick Fire Emissions Dataset (QFED) - Documentation of versions 2.1, 2.2, and 2.4, Technical Report series on Global Modeling and Data Assimilation, NASA/TM-2014-104606, edited by: Koster, R. D., in preparation, 2015.

Davis, K. J., Bakwin, P. S., Yi, C., Beger, B. W., Zhao, C., Teclaw, R. M., and Isebrands, J. G.: The annual cycles of $\mathrm{CO}_{2}$ and $\mathrm{H}_{2} \mathrm{O}$ exchange over a northern mixed forest as observed from a very tall tower, Glob. Change Biol., 9, 1278-1293, doi:10.1046/j.13652486.2003.00672.x, 2003.

Donnell, E. A., Fish, D. J., and Dicks, E. M.: Mechanisms for pollutant transport between the boundary layer and the free troposphere, J. Geophys. Res., 106, 7847-7856, doi:10.1029/2000JD900730, 2001.

Drummond, J. R. and Mand, G. S.: The Measurements of Pollution in the Troposphere (MOPITT) instrument: Overall performance and calibration requirements, J. Atmos. Ocean. Tech., 13, 314-320, doi:10.1175/15200426(1996)013<0314:TMOPIT>2.0.CO;2, 1996.

Duncan, B. N. and Logan, J. A.: Model analysis of the factors regulating the trends and variability of carbon monoxide between 1988 and 1997, Atmos. Chem. Phys., 8, 7389-7403, doi:10.5194/acp-8-7389-2008, 2008.

Duncan, B. N., Logan, J. A., Bey, I., Megretskaia, I. A., Yantosca, R. M., Novelli, P. C., Jones, N. B., and Rinsland, C. P.: The global budget of CO, 1988-1997: Source estimates and validation with a global model, J. Geophys. Res., 112, D22301, doi:10.1029/2007JD008459, 2007.

Fung, I. Y., Meyn, S. K., Tegen, I. Doney, S. C., John, J. G., and Bishop, J. K. B.: Iron supply and demand in the upper ocean, Global Biogeochem. Cy., 14, 281-295, doi:10.1029/1999GB900059, 2000.

Gerbig, C., Lin, J. C., Wofsy, S. C., Dabe, B. C., Andrews, A. E., Stephens, B. B., Bakwin, P. S., and Grainger, C. A.: Toward constraining regional-scale fluxes of $\mathrm{CO}_{2}$ with atmo- spheric observations over a continent: 1 . Observed spatial variability from airborne platforms, J. Geophys. Res., 108, 4756, doi:10.1029/2002JD003018, 2003.

Ginoux, P., Chin, M., Tegen, I., Prospero, J., Holben, B., Dubovik, O., and Lin, S.-J.: Sources and global distributions of dust aerosols simulated with the GOCART model, J. Geophys. Res., 106, 20255-20273, doi:10.1029/2000JD000053, 2001.

Gong, S. L.: A parameterization of sea-salt aerosol source function for sub- and super-micron particles, Global Biogeochem. Cy., 17, 1097, doi:10.1029/2003GB002079, 2003.

Gregg, W. W.: A coupled ocean general circulation, biogeochemical, and radiative model of the global oceans: seasonal distributions of ocean chlorophyll and nutrients. NASA Technical Memorandum 2000-209965, 33 pp., available at: http://ntrs. nasa.gov/archive/nasa/casi.ntrs.nasa.gov/20000112962.pdf (last access: 10 December 2014), 2000.

Gregg, W. W.: Tracking the SeaWiFS record with a coupled physical/biogeochemical/radiative model of the global oceans, DeepSea Res. Pt. II, 49 81-105, doi:10.1016/S0967-0645(01)000959, 2002.

Gregg, W. W. and Casey, N. W.: Modeling coccolithophores in the global oceans, Deep-Sea Res. Pt. II, 54, 447-477, doi:10.1016/j.dsr2.2006.12.007, 2007.

Gregg, W. W., Ginoux, P., Schopf, P. S., and Casey, N. W.: Phytoplankton and iron: validation of a global three-dimensional ocean biogeochemical model, Deep-Sea Res. Pt. II, 50, 3143-3169, doi:10.1016/j.dsr2.2003.07.013, 2003.

Gurney, K. R., Law, R. M., Denning, A. S., Rayner, P. J., Baker, D., Bousquet, P., Bruhwiler, L., Chen, Y.-H., Ciais, P., Fan, S., Fun, I. Y., Gloor, M., Heimann, M., Higuchi, K., John, J., Maki, T., Maksyutov, S., Masarie, K., Peylin, P., Prather, M., Pak, B. C., Randerson, J., Sarmiento, J., Taguchi, S., Takahaskhi, T., and Yuen, C.-W.: Towards robust regional estimates of $\mathrm{CO}_{2}$ sources and sinks using atmospheric transport models, Nature, 415, 626630, doi:10.1038/415626a, 2002.

Hamazaki, T., Kaneko, Y., Kuze, A., and Kondo, K.: Fourier transform spectrometer for greenhouse gases observing satellite (GOSAT), Proceedings of SPIE 5659, P. Soc. Photo.-Opt. Ins., 73, doi:10.1117/12.581198, 2005.

Helfand, H. M. and Schubert, S. D.: Climatology of the Simulated Great Plains Low-Level Jet and Its Contribution to the Continental Moisture Budget of the United States, J. Climate, 8, 784-806, doi:10.1175/1520-0442(1995)008<0784:cotsgp>2.0.co;2, 1995.

Holben, B. N., Eck, T. F., Slutsker, I., Tanré, D., Buis, J. P., Setzer, A., Vermote, E., Reagan, J. A., Kaufman, Y. J., Nakajima, T., Lavenu, F., Jankowiak, I., and Smirnov, A.: AERONET - A federated instrument network and data archive for aerosol characterization, Remote Sens. Environ., 66, 1-16, doi:10.1016/S00344257(98)00031-5, 1998.

Holtslag, A. A. M., Svensson, G., Baas, P., Basu, S., Beare, B., Beljaars, A. C. M., Bosveld, F. C., Cuxart, J., Lindvall, J., Steeneveld, G. J., Tjernström, M., and Van De Wiel, B. J. H.: Stable atmospheric boundary layers and diurnal cycles: Challenges for weather and climate models, B. Am. Meteorol. Soc., 94, 16911706, doi:10.1175/BAMS-D-11-00187.1, 2013.

Jickells, T. D., An, Z. S., Andersen, K. K., Baker, A. R., Bergametti, G., Brooks, N., Cao, J. J., Boyd, P. W., Duce, R. A., Hunter, K. A., Kawahata, H., Kubilay, N., LaRoche, J., Liss, P. S., Mahowald, N., Prospero, J. M., Ridgwell, A. J., Tegen, 
I., and Torres, R.: Global iron connections between desert dust, ocean biogeochemistry, and climate, Science, 308, 67-71, doi:10.1126/science.1105959, 2005.

Kahn, R. A., Gaitley, B. J., Garay, M. J., Diner, D. J., Eck, T. F., Smirnov, A., and Holben, B. N.: Multiangle Imaging SpectroRadiometer global aerosol product assessment by comparison with the Aerosol Robotic Network, J. Geophys. Res., 115, D23209, doi:10.1029/2010JD014601, 2010.

Kishcha, P., da Silva, A. M., Starobinets, B., and Pinhas, A.: Air pollution over the Ganges basin and northwest Bay of Bengal in the early postmonsoon season based on NASA MERRAero data, J. Geophys. Res.-Atmos., 19, 1555-1570, doi:10.1002/2013JD020328, 2014.

Koster, R. D., Suarez, M. J., Ducharne, A., Stieglitz, M., and Kumar, P.: A catchment-based approach to modeling land surface processes in a general circulation model: 1 . Model structure, J. Geophys. Res.-Atmos., 105, 24809-24822, doi:10.1029/2000jd900327, 2000.

Lin, J.-T. and McElroy, M. B.: Impacts of boundary layer mixing on pollutant vertical profiles in the lower troposphere: Implications to satellite remote sensing, Atmos. Environ., 44, 17261739, doi:10.1016/j.atmosenv.2010.02.009, 2010.

Lock, A. P., Brown, A. R., Bush, M. R., Martin, G. M., and Smith, R. N. B.: A New Boundary Layer Mixing Scheme. Part I: Scheme Description and Single-Column Model Tests, Mon. Weather Rev., 128, 3187-3199, doi:10.1175/15200493(2000)128<3187:anblms>2.0.co;2, 2000.

Louis, J., Tiedtke, M., and Geleyn, J.: A short history of the PBL parameterization at ECMWF, Workshop on Planetary Boundary Layer Parameterization, ECMWF, Reading, England, 527 November 1981, 59-79, 1982.

Mahowald, N.: Aerosol indirect effect on biogeochemical cycles and climate, Science, 334, 6057, doi:10.1126/science.1207374, 2011

Mahrt, L. and Vickers, D.: Formulation of turbulent fluxes in the stable boundary layer, J. Atmos. Sci., 60, 2538-2548, doi:10.1175/1520-0469(2003)060<2538:FOTFIT>2.0.CO;2, 2003.

Marland, G. and Rotty, R. M.: Carbon dioxide emissions from fossil fuels: a procedure for estimation and results for 1950-1982., Tellus B, 36, 232-261, doi:10.1111/j.1600-0889.1984.tb00245.x, 1984.

Marland, G., Boden, T. A., and Andres, R. J.: Global, regional, and national fossil fuel $\mathrm{CO}_{2}$ emissions, in Trends: A Compendium of Data on Global Change, Carbon Dioxide Inf. Anal. Cent., Oak Ridge Natl. Lab., Oak Ridge, Tenn., available at: http://cdiac.ornl.gov/trends/emis/overview.html (last access: 11 April 2014), 2008.

McGrath-Spangler, E. L. and Denning, A. S.: Impact of entrainment from overshooting thermals on land-atmosphere interactions during summer 1999, Tellus B, 62, 441-454, doi:10.1111/j.16000889.2010.00482.x, 2010.

McGrath-Spangler, E. L. and Molod, A.: Comparison of GEOS5 AGCM planetary boundary layer depths computed with various definitions, Atmos. Chem. Phys., 14, 6717-6727, doi:10.5194/acp-14-6717-2014, 2014

McGrath-Spangler, E. L., Denning, A. S., Corbin, K. D., and Baker, I. T.: Sensitivity of land-atmosphere exchanges to overshooting
PBL thermals in an idealized coupled model, J. Adv. Model. Earth Syst., 1, 14, doi:10.3894/JAMES.2009.1.14, 2009.

Molod, A., Takacs, L., Suarez, M. J., Bacmeister, J. T., Song, I.S., and Eichmann, A.: The GEOS-5 Atmospheric General Circulation Model: Mean Climate and Development from MERRA to Fortuna, Technical Report Series on Global Modeling and Data Assimilation, 28, 115 pp., available at: http://gmao.gsfc. nasa.gov/pubs/docs/tm28.pdf (last access: 4 March 2014), 2012.

Moorthi, S. and Suarez, M. J.: Relaxed Arakawa-Schubert. A Parameterization of Moist Convection for General Circulation Models, Mon. Weather Rev., 120, 978-1002, doi:10.1175/15200493(1992)120<0978:rasapo>2.0.co;2, 1992.

O’Dell, C. W., Connor, B., Bösch, H., O’Brien, D., Frankenberg, C., Castano, R., Christi, M., Eldering, D., Fisher, B., Gunson, M., McDuffie, J., Miller, C. E., Natraj, V., Oyafuso, F., Polonsky, I., Smyth, M., Taylor, T., Toon, G. C., Wennberg, P. O., and Wunch, D.: The ACOS $\mathrm{CO}_{2}$ retrieval algorithm - Part 1: Description and validation against synthetic observations, Atmos. Meas. Tech., 5, 99-121, doi:10.5194/amt-5-99-2012, 2012.

Ott, L. E., Pawson, S., Collatz, G. J., Gregg, W., Menemenlis, D., Brix, H., Rousseaux, C. S., Bowman, K., Liu, J., Eldering, A., Gunson, M., and Kawa, S. R.: Assessing the magnitude of $\mathrm{CO}_{2}$ flux uncertainty in atmospheric $\mathrm{CO}_{2}$ records using products from NASA's Carbon Monitoring Flux Pilot Project, J. Geophys. Res., 120, 734-765, doi:10.1002/2014JD022411, 2015.

Parazoo, N. C., Denning, A. S., Kawa, S. R., Corbin, K. D., Lokupitiya, R. S., and Baker, I. T.: Mechanisms for synoptic variations of atmospheric $\mathrm{CO}_{2}$ in North America, South America and Europe, Atmos. Chem. Phys., 8, 7239-7254, doi:10.5194/acp-87239-2008, 2008.

Parrish, D. D., Singh, H. B., Molina, L., and Madronich, S.: Air quality progress in North American megacities: A review, 45, 7015-7025, doi:10.1016/j.atmosenv.2011.09.039, 2011.

Pérez, N., Pey, J., Cusack, M., Reche, C., Querol, X., Andrés, A., and Viana, M.: Variability of particle number, black carbon, and $\mathrm{PM}_{10}, \mathrm{PM}_{2.5}$, and $\mathrm{PM}_{1}$ levels and speciation: Influence of road traffic emissions on urban air quality, Aerosol Sci. Tech., 44, 487-499, doi:10.1080/02786821003758286, 2010.

Potter, C. S., Randerson, J. T., Field, C. B., Matson, P. A., Vitousek, P. M., Mooney, H. A., and Klooster, S. A.: Terrestrial ecosystem production: A process-oriented model based on global satellite and surface data, Global Biogeochem. Cy., 7, 811-842, doi:10.1029/93GB02725, 1993.

Putman, W. M. and Lin, S.-J.: Finite-volume transport on various cubed-sphere grids, J. Comput. Phys., 227, 55-78, doi:10.1016/j.jcp.2007.07.022, 2007.

Randerson, J. T., Thompson, M. V., Conway, T. J., Field, C. B., and Fung, I. Y.: Substrate limitations for heterotrophs: Implications for models that estimate the seasonal cycle of atmospheric $\mathrm{CO}_{2}$, Global Biogeochem. Cy., 10, 585-602, doi:10.1029/96GB01981, 1996.

Randles, C. A., Colarco, P. R., and da Silva, A.: Direct and semi-direct aerosol effects in the NASA GEOS-5 AGCM: Aerosol-climate interactions due to prognostic versus prescribed aerosols, J. Geophys. Res.-Atmos., 118, 149-169, doi:10.1029/2012JD018388, 2013.

Remer, L. A., Kaufman, Y. J., Tanré, D., Mattoo, S., Chu, D. A., Martins, J. V., Li, R.-R., Ichoku, C., Levy, R. C., Kleidman, R. G., Eck, T. F., Vermote, E., and Holben, B. N.: The MODIS aerosol 
algorithm, products, and validation, J. Atmos. Sci., 62, 947-973, doi:10.1175/JAS3385.1, 2005.

Rienecker, M. M., Suarez, M. J., Todling, R., Bacmeister, J. T., Takacs, L., Liu, H.-C., Gu, W., Sienkiewicz, M., Koster, R., Gelaro, R., Stajner, I., and Nielsen, J. E.: The GEOS-5 Data Assimilation System - Documentation of Versions 5.0.1, 5.1.0, and 5.2.0, Technical Report Series on Global Modeling and Data Assimilation, 101 pp., available at: http://gmao.gsfc.nasa.gov/pubs/ docs/GEOS5_104606-Vol27.pdf (last access: 4 March 2014), 2008.

Rienecker, M. M., Suarez, M. J., Gelaro, R., Todling, R., Bacmeister, J., Liu, E., Bosilovich, M. G., Schubert, S. D., Takacs, L., Kim, G.-K., Bloom, S., Chen, J., Collins, D., Conaty, A., da Silva, A., Gu, W., Joiner, J., Koster, R. D., Lucchesi, R., Molod, A., Owens, T., Pawson, S., Pegion, P., Redder, C. R., Reichle, R., Robertson, F. R., Ruddick, A. G., Sienkiewicz, M., and Woollen, J.: MERRA: NASA's Modern-Era Retrospective Analysis for Research and Applications, J. Climate, 24, 3624-3648, doi:10.1175/jcli-d-11-00015.1, 2011.

Rosenfeld, D., Rudich, Y., and Lahav, R.: Desert dust suppressing precipitation: A possible desertification feedback loop, P. Natl. Acad. Sci., 98, 5975-5980, doi:10.1073/pnas.101122798, 2001.

Rossow, W. B. and Schiffer, R. A.: ISCCP cloud data products, B. Am. Meteorol. Soc., 72, 2-20, doi:10.1175/15200477(1991)072<0002:ICDP>2.0.CO;2, 1991.

Rossow, W. B. and Schiffer, R. A.: Advances in understanding clouds from ISCCP, B. Am. Meteorol. Soc., 80, 2261-2287, doi:10.1175/1520-0477(1999)080<2261:AIUCFI>2.0.CO;2, 1999.

Sandu, I., Beljaars, A., Bechtold, P., Mauritsen, T., and Balsamo, G.: Why is it so difficult to represent stably stratified conditions in numerical weather prediction (NWP) models?, J. Adv. Model. Earth. Syst., 5, 117-133, doi:10.1002/jame.20013, 2013.

Seibert, P., Beyrich, F., Gryning, S.-E., Joffre, S., Rasmussen, A., and Tercier, P.: Review and intercomparison of operational methods for the determination of the mixing height, Atmos. Environ., 34, 1001-1027, doi:10.1016/s1352-2310(99)00349-0, 2000.

Seidel, D. J., Ao, C. O., and Li, K.: Estimating climatological planetary boundary layer heights from radiosonde observations: Comparison of methods and uncertainty analysis, J. Geophys. Res., 115, D16113, doi:10.1029/2009jd013680, 2010.

Seidel, D. J., Zhang, Y., Beljaars, A., Golaz, J.-C., Jacobson, A. R., and Medeiros, B.: Climatology of the planetary boundary layer over the continental United States and Europe, J. Geophys. Res.Atmos., 117, D17106, doi:10.1029/2012jd018143, 2012.
Sherwood, S. C., Bony, S., and Dufresne, J.-L.: Spread in model climate sensitivity traced to atmospheric convective mixing, Nature, 505, 7481, doi:10.1038/nature12829, 2014.

Sinclair, V. A., Gray, S. L., and Belcher, S. E.: Boundary-layer ventilation by baroclinic life cycles, Q. J. Roy. Meteor. Soc., 134, 1409-1424, doi:10.1002/qj.293, 2008.

Sokolik, I. N. and Toon, O. B.: Direct radiative forcing by anthropogenic airborne mineral aerosols, Nature, 381, 681-683, doi:10.1038/381681a0, 1996.

Stull, R. B.: An introduction to boundary layer meteorology, Kluwer Academic Publishers, Norwell, MA, 666 pp., 1988.

Troen, I. B. and Mahrt, L.: A simple model of the atmospheric boundary layer; Sensitivity to surface evaporation, Bound.-Lay. Meteorol., 37, 129-148, doi:10.1007/BF00122760, 1986.

van der Werf, G. R., Randerson, J. T., Giglio, L., Collatz, G. J., Mu, M., Kasibhatla, P. S., Morton, D. C., DeFries, R. S., Jin, Y., and van Leeuwen, T. T.: Global fire emissions and the contribution of deforestation, savanna, forest, agricultural, and peat fires (19972009), Atmos. Chem. Phys., 10, 11707-11735, doi:10.5194/acp10-11707-2010, 2010.

Vogelezang, D. H. P. and Holtslag, A. A. M.: Evaluation and model impacts of alternative boundary-layer height formulations, Bound.-Lay. Meteorol., 81, 245-269, doi:10.1007/bf02430331, 1996.

Wunch, D., Wennberg, P. O., Toon, G. C., Connor, B. J., Fisher, B., Osterman, G. B., Frankenberg, C., Mandrake, L., O’Dell, C., Ahonen, P., Biraud, S. C., Castano, R., Cressie, N., Crisp, D., Deutscher, N. M., Eldering, A., Fisher, M. L., Griffith, D. W. T., Gunson, M., Heikkinen, P., Keppel-Aleks, G., Kyrö, E., Lindenmaier, R., Macatangay, R., Mendonca, J., Messerschmidt, J., Miller, C. E., Morino, I., Notholt, J., Oyafuso, F. A., Rettinger, M., Robinson, J., Roehl, C. M., Salawitch, R. J., Sherlock, V., Strong, K., Sussmann, R., Tanaka, T., Thompson, D. R., Uchino, O., Warneke, T., and Wofsy, S. C.: A method for evaluating bias in global measurements of $\mathrm{CO}_{2}$ total columns from space, Atmos. Chem. Phys., 11, 12317-12337, doi:10.5194/acp11-12317-2011, 2011.

Yevich, R. and Logan, J. A.: An assessment of biofuel use and burning of agricultural waste in the developing world, Global Biogeochem. Cy., 17, 1095, doi:10.1029/2002GB001952, 2003.

Yokota, T., Oguma, H., Morino, I., and Inoue, G.: A nadir looking SWIR FTS to monitor $\mathrm{CO}_{2}$ column density for Japanese GOSAT project, Proc. Twenty-fourth Int. Sympo. On Space Technol. And Sci. (Selected Papers), Miyazaki, Japan, 30 May-6 June 2004, 887-889, 2004. 